\title{
Searching for Hijackers: Constitutionality, Costs, and Alternatives
}

In 1930, a group of Peruvian revolutionaries commandeered a Ford trimotor aircraft and perpetrated the world's first recorded airplane hijacking. ${ }^{1}$ Since then there have been 394 hijacking attempts, ${ }^{2}$ of which 248 have been successful. ${ }^{3}$ Most attempts have occurred in the last five years, ${ }^{4}$ prompting some to proclaim the existence of a hijacking "epidemic."5 In an effort to prevent would-be hijackers from boarding aircraft, preboarding security procedures have been instituted at airports ${ }^{6}$ - procedures that raise serious constitutional ${ }^{7}$ and policy questions. This comment first describes the history of airplane hijacking and the United States response to the problem. It then discusses the constitutionality of the airport security program and compares its costs

1 J. AREy, The Sky Pirates (1972); FAA, Office of Air Transportation Security, Domestic and Foreign Aircraft Hijackings, Dec. 1, 1972 [hereinafter cited as Domestic and Foreign Aircraft Hijackings].

2 U.S. Dep't of Transportation, FAA, Hijacking Attempts on U.S. Registered Aircraft, Jan. 12, 1973 [hereinafter cited as Hijacking Attempts on U.S. Registered Aircraft]. FAA, Office of Air Transportation Security, Worldwide Reported Hijacking Attempts, Dec. 1, 1972, reports 391 attempted hijackings since 1930; this minor discrepency results from different figures for the number of foreign hijackings in 1969, 1970, and 1972. The FAA and the Justice Department do not always agree on whether an incident should be considered a hijacking attempt. See note 47 infra. The incidence of such disagreement, however, is rare, and the only distinction seems to be where the offender has no diversionary motive, but only one of sabotage or self-destruction. Such cases are considered hijackings by the Justice Department, but not by the FAA.

3 Id. The FAA classifies all hijackings as "successful," "incomplete," or "unsuccessful." A successful hijacking is one in which the hijacker controls the flight and reaches his "destination or objective." An incomplete hijacking is one in which the "hijacker is apprehended/killed during the hijacking or as a result of "hot pursuit.'" An unsuccessful hijacking is one in which the hijacker attempts to take control of the flight but fails. FAA, Office of Air Transportation Security, Hijacking Statistics, Dec. 1, 1972. For the purposes of this comment, "unsuccessful" and "incomplete" hijackings are treated as one group.

4 Between 1930 and 1967, there were sixty-five attempts; between 1968 and December 31, 1972, there were 329 attempts. Domestic and Foreign Aircraft Hijackings, supra note 1.

5 See Friedlander, Politics, Economics and Skyjacking, N.Y. Times, Dec. 3, 1972, § 10, at 47 , col. 1 .

o See Fenello, Technical Prevention of Air Piracy, 585 InT't Concilmation 28 (1971); U.S. Dep't of Transportation, News, 69-119, Oct. 15, 1969.

7 See Abramovsky, The Constitutionality of the Anti-Hijacking Security System, 22 Buffalo L. Rev. 123 (1972); McGinley \& Downs, Airport Searches and Seizures-A Reasonable Approach, 41 Fordham L. Rev. 293 (1972); Note, Airport Security Searches and the Fourth Amendment, 71 CoLum. L. REv. 1039 (1971); Dershowitz, Stretching the Fourth Amendment, N.Y. Times, Dec. 24, 1972, \& 4, at 2, col. 1. 
to those of alternative measures that may be at least as effective as those currently in use. The comment concludes that certain aspects of the present program are both unconstitutional and unwise.

\section{History}

Between July, 1947, and March, 1953, there were sixteen attempted hijackings, ${ }^{8}$ fourteen of which succeeded. ${ }^{9}$ The successful hijackings all involved refugees fleeing from Eastern European countries, ${ }^{10}$ and the abrupt halt of such hijackings in 1953 may have been the result of intensified security measures, including travel restrictions, in those countries. ${ }^{11}$ A new series of hijackings began in 1958 and continued through 1960.12 During this period, there were eleven successful and five unsuccessful attempts, most of which involved Cubans fleeing from the Castro regime to the United States. ${ }^{13}$ In 1961, the United States began offering free transportation to persons who gained permission to leave $\mathrm{Cuba}^{14}$ and perhaps because of this, the Cuba-United States traffic ended. After 1961, the traffic was reversed. United States-to-Cuba hijacking attempts, the first of which occurred in that year, ${ }^{15}$ reached their peak in 1968 and $1969 .{ }^{16}$ Restrictions on travel to Guba during the $1960 \mathrm{~s}^{17}$ seem to have been a primary cause of these hijackings. ${ }^{18}$ The fourth phase ${ }^{19}$ of hijacking includes recent extortionist hijackings ${ }^{20}$

\footnotetext{
8 Domestic and Foreign Aircraft Hijackings, supra note 1.

9 Aggarwala, Political Aspects of Hijacking, 585 InT'L Conguiation 7, 8 (1971).

10 Id.

11 Id.

12 Domestic and Foreign Aircraft Hijackings, supra note 1.

13 Political Aspects of Hijacking, supra note 9, at 8-10.

1445 U.S. DEp'T of STATe BuLL. 238 (1961). It was originally expected that the flights would permit twenty thousand Cubans to come to the United States over a period of three weeks in July and August of 1961. The flights continued, however, until the Cuban missile crisis in October, 1962. 48 id. 983, at 984 (1963). In 1965, the so-called "Freedom Airlift" was initiated, bringing Cubans who wanted to leave to Miami. 53 id. 950 (1965). The flights were recently terminated. Chicago Sun Times, Apr. 7, 1973, at 5, col. 2.

I5 See FAA, Office of Air Transportation Security, Chronology of Hijackings of U.S. Registered Aircraft, Dec. 1, 1972 [hereinafter cited as Chronology of U.S. Hijackings].

16 Cuba was the destination of fifty-six of the sixty-two attempted hijackings in 19681969. Between 1970 and 1972 , it was the destination in only thirty-six of eighty-five attempted hijackings. Id.; Hijacking Attempts on U.S. Registered Aircraft, supra note 2.

1745 U.S. DEP'T OF STATE BuLx. 108 (1961).

18 See House Comm. on Foreign Affatrs, Subcomm. on Inter-American Affairs, 90th Cong., 2d Sess., Air Piracy in rhe Caribbean Area 2, 7-8 (Comm. Print 1968). The report suggested that "an alternative mode of transportation may give second thought to those who may rashly attempt a hijacking operation." Id. at 8.

19 There can be little doubt that the Cuba phase is virtually over. In 1972, of thirty-one attempted hijackings, only seven were directed to securing passage to Cuba. Hijacking Attempts on U.S. Registered Aircraft, supra note 2.

20 There were thirty-five attempts on U.S. aircraft between November 24, 1971, when
} 
and the hijacking and sabotage of aircraft by terrorists in connection with hostilities in the Middle East. ${ }^{21}$

While the first American hijacking was regarded as a freak, ${ }^{22}$ the second, which occurred less than three months later, ${ }^{23}$ caused an uproar. ${ }^{24}$ Congress promptly amended the Federal Aviation $\mathrm{Act}^{25}$ to make hijacking a federal crime punishable by death, with a minimum sentence of twenty year's imprisonment, ${ }^{26}$ and to authorize the airlines to refuse transportation to passengers who, in the airline's opinion, were "inimical to safety of flight."27 Although House and Senate committees have since held hearings on the subject on several occasions, ${ }^{28}$ the 1961 amendments remain the only substantive congressional enactment concerning hijacking. ${ }^{29}$ Primary responsibility for dealing with hijacking has, therefore, devolved upon the Federal Aviation Administration.

Between 1961 and 1967 there were relatively few hijacking attempts, ${ }^{30}$ and the FAA, using its rule making authority, issued only one minor regulation directed to the problem. ${ }^{31}$ In 1968, however, a marked increase in the number of domestic attempts ${ }^{32}$ sparked renewed interest in finding ways to end hijacking. ${ }^{33}$ The State Department announced that it would allow Cuban exiles wanting to return home to do so, free of charge, on Freedom Airlift return flights. ${ }^{34}$ A House subcommittee report on hijacking recommended similar action and also encouraged the development of electronic and other devices to

"D. B. Cooper" made history as the first parachute extortionist, and December 5, 1972, when the FAA imposed its strict security regulations, see text at notes 70-72 infra. Of the thirty-five attempts, twenty-two have been extortionist in nature.' Chronology of U.S. Hijackings, supra note 15 .

21. There have been fifteen such hijacking attempts: eight between August, 1969 and September, 1970; none between September, 1970, and September, 1971; and seven between September, 1971 and the present. Domestic and Foreign Aircraft Hijackings, supra note 1. 22 See N.Y. Times, May 2, 1961, at 1, col. 6, referring to the affair the day before as "the Cuban incident" and describing it, not as the first U.S. hijacking, but as a "forced detour."

23 The first incident occurred on May 1, 1961; the second on July 24. Chronology of U.S. Hijackings, supra note 15.

24 News related to the incident appeared on the front page of the New York Times for six consecutive days. In large part, this was due to the Cuban government's position on the return of the plane. See 45 U.S. DEP'T OF STATE BuLL. 334, 335-36 (1961). (The passengers and crew had been allowed to return the day after the hijacking. Id.) Following the Castro takeover, many of the planes and boats diverted by Cuban refugees fleeing to this country were attached by court process and sold in satisfaction of debts owed by Cuba to American citizens. Id. at 275, 277-78; McWhinney, International Legal Problem-Solving and the Practical Dilemma of Hijacking, in AERIAL PIRACY AND INTERNATTONAL LAW 15, 16 (E. McWhinney ed. 1971). The Cubans demanded that a patrol boat be exchanged for the American plane in their custody; the United States complied. 45 U.S. DEP'T of STATE BuLL. 407 (1961). Much of the news, however, concerned recognition of the seriousness of hijacking and the need for severe penalties. See N.Y. Times, July 29, 1961, at 1, col. 5. 
detect hijackers prior to boarding. ${ }^{35}$ In response, the FAA established a Task Force on the Deterrence of Air Piracy in February, 1969. ${ }^{36}$ Within a few months, it had developed the "Behavioral Profile,"37 a checklist of about a dozen ${ }^{38}$ characteristics of past hijackers. The Profile, to be used with a magnetometer, a metal sensitive device for detecting weapons, ${ }^{39}$ was designed to help the airlines identify potential hijackers before they boarded the airplane.40

2549 U.S.C. $\S \S 1301$ et seq. (1970).

26 Id. § 1472(i).

27 Id. § 1511.

28 See Hearings on the Administration's Emergency Anti-Hijacking Regulations Before the Subcomm. on Aviation of the Senate Comm. on Commerce, 93 Cong., 1st Sess. (1973); Hearing on the Anti-Hijacking Act of 1971 Before the Subcomm. on Aviation of the Senate Comm. on Commerce, 92d Cong., 2d Sess. (1972); Hearing on S. 2176 to Implement the Convention on Offenses and Certain Other Acts Committed on Board Aircraft and for Other Purposes Before the Senate Comm. on Commerce, 91st Cong., 2d Sess. (1970); Hearings on Resolutions Referred to the Comm. on Foreign Affairs Concerning Aircraft Hijacking and Related Matters Before the House Comm. on Foreign Affairs, 91st Cong., 2d Sess. (1970).

29 Congress did pass Pub. L. 91-449, 84 Stat. 921 (May 14, 1970), but this was merely a technical provision extending jurisdiction to offenses on board aircraft over the high seas, as required by the Tokyo Convention. See note 216 infra.

30 Between 1961 and 1967, there were twelve attempted hijackings of U.S. registered aircraft; six of the seven successes were directed to Cuba. Chronology of U.S. Hijackings, supra note 15 .

31 See 29 Fed. Reg. 6003 (1964), adopting 14 C.F.R. 40.373, requiring that cockpit doors be closed and locked during flight. Regulations prohibiting admission of passengers to the cockpit had been in effect for some time prior to adoption of this rule and doors with locks had been required equipment on most airplanes. Many of the comments received on the proposed rules took the position that locked cockpit doors would not prevent the taking of hostages. $I d$.

32 There were twenty-two attempted hijackings of U.S. registered aircraft in 1968, as compared with one the year before. Nineteen hundred sixty-eight was a notable year worldwide: thirty-five hijackings were attempted as compared with six in 1967. Domestic and Foreign Aircraft Hijacking, supra note 1.

33 Diplomatic negotiations to arrange an extradition agreement with Cuba, N.Y. Times, Jan. 13, 1969, at 46, col. I (editorial), and air transportation boycotts against countries refusing to return hijackers, N.Y. Times, Jan. 10, 1969, at 46, col. 4, were both suggested. House Republicans introduced a bill to require bullet proofing of all pilot cabins on commercial aircraft. N.Y. Times, Dec. 1, 1968, at 33, col. 1.

34 N.Y. Times, July 12,1968 , at 64 , col. 1.

35 House Comm. on Foreign Affairs, supra note 18, at 7-8.

36 H. Reighatd, Foreword to FAA Task Force on Deterrence of Air Piracy, Hijack REFERENCE DATA (1970).

37 See generally J. Dailey, Development of a Behavioral Profile for Air Pirates (paper prepared for Ninth Annual Law Review Symposium, Villanova Law School) (copy on file at The University of Chicago Law Review).

38 Fenello, supra note 6 , at $30-31$.

38 U.S. Dep't of Transportation, News, 69-119, Oct. 15, 1969. See also FAA TASK Force on Deterrence of Air Piracy, U.S. Efforts to Deter Hijacking, 15-16 (1970); J. Dailey, supra note 37 , at 8-10.

40 An additional security measure, though short-lived, deserves mention. In response to 
The FAA, recognizing from the outset that the Profile/magnetometer screening system was imperfect, intended the system primarily as a deterrent. ${ }^{41}$ Its implementation was left to the discretion of the airlines, most of which did not use it at first due to fear of adverse reaction from the travelling public.42 Eastern Airlines, which prior to mid-1969 had suffered most from hijacking, ${ }^{43}$ became the first airline to test the new system. ${ }^{44}$ At the check-in counter, ticket agents identified passengers fitting the Profile as "selectees," giving them color-coded boarding passes. All passengers were required to walk through the magnetometer prior to boarding, but only Profile selectees who activated the mag-

the hijacking and destruction of three jets at a remote desert strip in Jordan in early September, 1970, President Nixon hastily announced that armed incognito agents would ride airlines flying routes that had proved most vulnerable to hijacking. White House Press Release, Sept. 11, 1970, 63 U.S. DEP'T OF STATE BULL. 341 (1970). The Department of Transportation had previously offered guard protection at the request of an air carrier. Statement of John A. Volpe, Secretary of Commerce, Hearings on S. 4383 Before the Senate Comm. on Finance, 9lst Cong., 2d Sess. (1970). These guards were vested with law enforcement powers through designation by the attorney general as deputy U.S. marshals. Id. President Nixon's plan would have utilized such guards-there were then about 1300immediately, supplemented by specially trained members of the armed forces, while an adequate civilian force was being trained. White House Press Release, supra. The Department of Transportation hoped to train and employ 2,500 new guards, at a cost of $\$ 28$ million, to carry out the program. Statement of John A. Volpe, supra. UItimately, the "sky marshal" program failed because Congress did not vote the necessary funds. A bill passed the House providing for the temporary expenditure of funds from the Airport and Airways Trust Fund. H.R. 19414, 91st Cong., 2d Sess. (1970). The Senate Finance Committee, however, never reported this bill, nor did it report a similar Senate bill, S. 4383, 91st Cong., $2 d$ Sess. (1970), authorizing the secretary of transportation to provide guards for commercial aircraft and funding the measure by an increase in the domestic airway ticket tax. The proposal was controversial; in hearings before the full House Committee on Foreign Affairs the plan was attacked as impractical, ineffectual, and a threat to the safety of passengers. See Hearings Before the House Comm. on Foreign Affairs, supra note 28, at 95-97, 130. Though there had been instances in which armed guards on an $\mathrm{El} \mathrm{Al}$ airplane and a Brinks guard on a TWA jet shot hijackers, thus preventing diversion of the flight, even those in favor of the sky marshal plan realized that it was at best a temporary solution which would not work if a hijacker succeeded in using a hostage as a shield and could result in a mid-air shoot out that would be more hazardous than compliance with the hijacker's demands. Id. at 132. Moreover, the president's plan would have covered only a fraction of the fourteen thousand daily flights of U.S. aircraft. Thus, the possibility still remained that hijackers would simply divert their efforts to routes that did not appear to be vulnerable, but that were nonetheless served by jets with long-range capabilities.

41 FaA Task Forge on Deterrence of Air Piracy, U.S. Efforts to Deter Hijacking 20 (1970); Fenello, supra note 6, at 28-30; U.S. Dep't of Transportation, News, 69-135, Dec. 10, 1969, at 3; cf. J. Dailey, stppra note 37, at 11, observing that, although the greatest benefit from the system in the early stages would be deterrence, the system could become "a positive prevention measure" if coverage became "substantial or even complete."

42 Fenello, sitpra note 6 , at 29.

43 Eastern had been the victim of eighteen of sixty-seven domestic hijacking attempts between 1961 and September, 1969, and twelve of thirty-four attempts in the first nine months of 1969. Chronology of U.S. Hijackings, supra note 15.

44 U.S. Dep't of Transportation, News, 69-119, Oct. 15, 1969; Fenello, supra note 6, at 29. 
netometer were detained. If the persons detained failed to present identification and explain the activation of the magnetometer, they were subjected to a "pat-down" search and arrested if violations of the law were detected. 45

Despite the dramatic hijacking and subsequent destruction of three large aircraft in September, 1970,46 implementation of the FAA's Profile/magnetometer screening system continued to be voluntary. The system seemed to work well where used, ${ }^{47}$ and FAA Administrator John Shafer claimed that no flight had been hijacked after passengers had been screened. ${ }^{48}$ The reason for this soon became clear: since the system was used only on routes considered particularly vulnerable to diversion due to their proximity to Cuba, hijackers began focusing their attention on other flights ${ }^{49}$ and diverting flights to destinations other than Cuba. ${ }^{50}$ Each route's vulnerability to hijacking became less a function of its proximity to Cuba and more a function of whether it was served by a jet.51

45 According to Mr. Fenello, where an identification check was made for one passenger, "at least one or two additional passengers" were also stopped. This procedure, it was hoped, would protect the secrecy of the Profile, and "keep any passenger from interpreting the airline's action as being discriminatory due to race, color, or creed, factors which are not a part of the basic profile." Fenello, supra note 6 , at 31 .

46 N.Y. Times, Sept. 7, 1970, at 1, col. 4; Washington Post, Sept. 8, 1970, at A-1, col. 6; see note 40 supra.

47 From October, 1969, through December, 1971, Eastern Airlines experienced only nine hijacking attempts (one of which, that of March 17, 1970, was considered only by the Justice Department, not the FAA, as an attempt), as compared with twelve attempts in the first nine months of 1969. Chronology of U.S. Hijackings, supra note 15; see note 44 supra. Eastern considered the system a "continuing success in hijack prevention." Fenello, supra note 6, at 33. In December, 1969, TWA became the second carrier to use the Profile/ magnetometer system, U.S. Dep't of Transportation, News, 69-135, Dec. 10, 1969, and Pan American joined in January, 1970, U.S. Dep't of Transportation, News, 70-41, May 6, 1970 at 2. By the end of 1971, all United States commercial carriers were using at major terminals a security system based entirely or in part on the FAA program. Fenello, supra note 6 , at 30 .

48 U.S. Dep't of Transportation, News, 70-57, June 15, 1970, at 2.

49 Chronology of U.S. Hijackings, supra note 15. In the fifteen months between October, 1970, and January, 1972, there were thirty-six attempted hijackings of United States commercial airliners; twenty-five of these occurred on routes originating from or bound for cities other than those in Florida or Puerto Rico and twenty-one occurred on flights wholly outside the southeastern United States. $I d$.

60 In 1969, thirty-seven of the forty attempted hijackings of United States commercial aircraft were aimed at securing passage to Cuba. In 1970, in at least nine of the twentyseven attempted hijackings the hijacker announced a destination other than Cuba. In 1971, this figure rose to thirteen, while the number of attempts remained constant. And in 1972, twenty-five of thirty-one hijackings had some objective other than Cuba. Id.

51 No route served by a jet was immune to the threat of diversion. In the last quarter of 1971, for example, routes as diverse as Anchorage-to-Bethel, Portland-to-Seattle, and Albuquerque-to-Chicago were the target of hijack attempts; these attempts were, respectively, incomplete to Cuba, a successful parachute extortion, and successful to Cuba. Id. 
In a notice of proposed rule making in September, 1971, Administrator Shafer observed that the voluntary screening program was not providing the "needed protection in many instances." 52 He proposed that all air carriers, within ninety days of the effective date of the proposal, submit a security program to prevent hijacking of its airplanes. ${ }^{53}$ Between September, when this proposal was issued, and January, 1972, there were thirteen attempted hijackings, five of which succeeded. ${ }^{54}$ Of the eight unsuccessful hijackings, six involved extortion demands and four of those included requests for parachutes. ${ }^{55}$ Because of this "alarming" increase in hijacking, "including extortion of large sums of money," 56 the FAA issued an emergency regulation ${ }^{57}$ on January 31, 1972, requiring all air carriers, before February 6, 1972, to "adopt and put into use a screening system, acceptable to the Administrator, to prevent or deter the carriage aboard its aircraft of any sabotage device or weapon in carry-on baggage or on or about the persons of passengers ...."58 In the order, Administrator Shafer observed that the Profile/magnetometer screening system had been effective where used and, in the opinion of the FAA, could have prevented "a majority of the air piracies occurring recently" had it been used to the fullest possible extent. ${ }^{59}$ But since the regulation did not specify what

5236 Fed. Reg. 19173 (1971).

53 Id.

54 Chronology of U.S. Hijackings, supra note 15. Of these five, one was the famous "D. B. Cooper" parachute extortion affair. Actually, Cooper was not the pioneer he was widely thought to be. He was not the first to attempt to extort money; on June 4, 1970, an American, Arthur B. Barkley, had demanded that he be paid $\$ 100,000$ in ransom. Nor was Cooper the first to attempt to make a parachute getaway; a Scot named Paul J. Cini tried and was captured when he put down his gun to strap on his parachute on an Air Canada flight over Alberta, about two weeks before Cooper's exploit. But Cooper received the most publicity, probably because of his successful use of the parachute. Within a short time after Cooper's jump there was a popular song praising his exploits, "D. B. Cooper" sweatshirts flooded the market, and a bowling alley in Seattle offered a "D. B. Cooper Bowling Sweepstakes" with cash prizes. The Skyjacker and How to Stop Him, SATURDaY Review, Aug. 26, 1972, at 46. For a discussion of the faddish effect of the Cooper affair, see note 69 infra.

55 Chronology of U.S. Hijackings, supra note 15.

5637 Fed. Reg. 2500, 2501 (1972).

ธ7 Id.

58 Id. at 2501 (emphasis added).

50 Id. Despite Mr. Shafer's confidence in the screening system and the authority, conferred on him by the "acceptable to the Administrator" language of the January 31 order, to require airlines to employ it on every flight, the FAA's policy following the order was, until December 5, 1972: "to require as a minimum use of the Profile . . . Air carriers that had detection devices were required to use them to the maximum extent of their availability. The minimum use of both Profile and detection device was required on certain designated flights which were considered to be more susceptible to aerial piracy than others." Letter from V.L. Krohn, Chief, Operations Liaison Staff, Office of Air Transportation Security, FAA, to The University of Chicago Law Review, Feb. 5, 1973. Thus, the FAA never ordered total screening on all flights. Only vulnerable routes were covered by the system; 
type of screening system would be "acceptable to the Administrator," its real import lay in the power that it gave the administrator to review the airlines' security plans and order changes summarily..$^{60}$ Thus, for the first time, the antihijacking procedures used by the airlines were brought under the direct control of the FAA.

In the nine week period from March to early May, 1972, and again in June and July, 1972, more hijackings occurred, ${ }^{61}$ most of them extortion attempts. ${ }^{62}$ The FAA responded in June by proposing that aircraft with ventral or tail cone exits be modified so that the exits could not be opened in flight. ${ }^{63}$ This proposal was not approved until November and compliance was not required before August, 1973.04 However, by August, 1972, extortion hijackings had abated. ${ }^{65}$ Apparently nothing fails like failure, and in extortion hijackings, everyone, with one possible exception, ${ }^{66}$ had failed. ${ }^{67}$ The airlines have been closing tail exits during scheduled maintenance periods, ${ }^{68}$ and the para-

on other routes, screening remained essentially voluntary. But the vulnerable route theory had proved vulnerable itself in the months following the president's 1970 message. By the end of 1971, all major airlines were using the Profile/magnetometer system on the routes they considered most vulnerable; yet hijackers simply turned to other routes. Because of the continuing incidence of hijacking, the FAA had found it necessary to act in September, 1971, and again the following January to require all airlines to develop and implement a security system "acceptable to the Administrator." Interpreting this language as merely requiring the securing of vulnerable routes meant, in essence, that nothing had changed.

60 The notice stated that further rule making action would be taken shortly to implement the balance of the September proposal, which gave the administrator the power to order changes in a carrier's security plan on his own initiative where he found that "safety in air transportation and the public interest" so required. 36 Fed. Reg. 19174 (1971). The amendment provision was adopted at the end of February in an emergency rule making action implementing the earlier September proposal in full. 37 Fed. Reg. 4904 (1972). The amendment provision is significant because it is the authority relied on by the FAA for the increased security measures ordered on December 5, 1972. Telegram from FAA to all FAA Regional Directors, Dec. 5, 1972, copy on file at The University of Chicago Law Review.

61 In 1972 there were eleven attempts between March 7 and May 5 and eleven more between June 2 and July 31 . Chronology of U.S. Hijackings, supra note 15.

62 Four of the March-May group and nine of the June-July group were extortions. Id. 6337 Fed. Reg. 12507 (1972).

6437 Fed. Reg. 25354-55 (1972).

65 There have been only three hijack attempts since July 31, 1972-on August 18, October 29, and November 10, 1972. The August and November attempts included demands for money. Chronology of U.S. Hijacking, supra note 15.

66 Cooper succeeded in jumping out of the aircraft over some very rough country in southern Washington. However, none of the marked money he had with him was ever recovered, prompting speculation that he may have died during or shortly after his jump. The Skyjacker and How to Stop Him, supra note 54, at 51.

67 Only six hijackers had even succeeded in jumping out of the aircraft, although fifteen had demanded that parachutes be brought on board. Chronology of U.S. Hijackings, supra note 15.

68 Letter from V.L. Krohn, supra note 59. 
chute gambit seems to have become a short-lived, though colorful, episode in hijacking history.

The last five months of 1972 witnessed only three attempted hijackings of United States-registered aircraft, ${ }^{69}$ fewer than in any comparable period since 1967. Nonetheless, in December, 1972, the FAA issued its most far-reaching order, ${ }^{70}$ apparently in response to two dramatic and violent hijackings in October and early November. ${ }^{71}$ The order, effec-

68 Chronology of U.S. Hijackings, supra note 15. Though U.S. hijacking attempts actually increased in 1972, see Hijacking Attempts on U.S. Registered Aircraft, supra note 2, this statistic is misleading. The following table shows United States and foreign hijacking attempts from August through December for the last five years:

\begin{tabular}{lccccc}
\hline & 1972 & 1971 & 1970 & 1969 & 1968 \\
\hline U.S. Attempts & 3 & 10 & 15 & 13 & 12 \\
Foreign Attcmpts & 13 & 16 & 21 & 28 & 8 \\
\hline
\end{tabular}

Chronology of U.S. Hijackings, supra note 15; Domestic and Foreign Aircraft Hijackings, supra note 1. Though both the U.S. and foreign nations experienced "peaks" in 1969 and 1970, the domestic decline has been more precipitous than the foreign decline.

For purposes of long-term comparisons, utilization of the August-December figures is appropriate if the January-July, 1972, period is viewed as an unusual one during which hijackers attempted to try out the "new" extortion gambit pioneered (with parachute) by "Cooper." See text and note at note 54 supra. This view seems justified by comparing U.S. and foreign attempts during January-July over the last five years:

\begin{tabular}{lccccc}
\hline & 1972 & 1971 & 1970 & 1969 & 1968 \\
\hline U.S. Attempts & 28 & 17 & 13 & 27 & 10 \\
Foreign Attempts & 19 & 16 & 34 & 19 & 5 \\
\hline
\end{tabular}

Chronology of the U.S. Hijackings, supra note 15. The U.S. activity in January-July, 1972, seems clearly out of step with both U.S. and foreign trends.

Given these figures, a strong argument can be made that, had it not been for the faddish interest in extortions following the Cooper affair, see text and notes at notes 20, 61-62, the number of attempts in 1972 would have been very small indeed. This in turn indicates that the FAA's Profile/magnetometer system, even though applied only on a voluntary basis by the airlines, was quite effective as a deterrent.

70 U.S. Dep't of Transportation, News, 103-72, Dec. 5, 1972.

71 Chronology of U.S. Hijackings, supra note 15 . On October 29,1972 , four men wanted in connection with a bank robbery in Virginia forced their way onto a jet in Houston and diverted it to Cuba. In the process of boarding the plane, they shot and killed a ticket agent, and wounded a ramp serviceman. N.X. Times, Oct. 30, 1972, at 1, col. 2. On November 10,1972, three men-two of whom were wanted on rape charges and one of whom was a fugitive from jail-boarded a Southern Airways jet in Birmingham, Alabama, and diverted it to Cuba. The drama lasted twenty-nine hours, during which time the jet, with all passengers aboard, shuttled four thousand miles up and down the eastern United States, landing at eight airports, one of which was Havana, before finally landing at Havana again. The co-pilot was wounded in the arm, either by the hijackers or by the FBI, who shot out the plane's tires in Orlando. The hijackers demanded $\$ 10$ million in ransom and were paid over $\$ 2$ million, which was confiscated, but later returned, by authorities in Havana. N.Y. Times, Nov. 13, 1972, at 1, col. 1; see note 183 infra. 
tive January 5, 1973, requires electronic screening of all passengers as a condition of boarding, and inspection by the airlines of all carry-on items accessible to passengers during flight. ${ }^{72}$ In a related action, the FAA also required airport operators to provide, by February 6, 1973, armed law enforcement officers at all boarding gates during the boarding process. ${ }^{73}$ This rule went into effect on February 16, after an attempt to have it permanently enjoined had failed..$^{4}$

The government's response to hijacking has been sporadic and not always well advised. The initial decision to study ways of thwarting hijackers and the decision to seal tail exits to prevent parachute hijackings seem clearly appropriate. In other cases, the response has been questionable. ${ }^{75}$ Between 1968 and 1972 the FAA clung to the vulnerable route theory, ${ }^{76}$ even though hijacker objectives and destinations had changed markedly during that time. And, although it clearly had the power to do so, ${ }^{77}$ the FAA never required limited Profile/magnetometer screening on all flights. Instead, it moved from a system that remained largely voluntary prior to December, 1972, to a system of total security-suddenly requiring armed guards and searches of carryon luggage at a time when hijacking was at its lowest ebb in five years.

\section{The Constitutionality of Airport Searches}

Airport searches raise two distinct types of constitutional problems: first, whether and in what circumstances airport searches are permissible under the fourth amendment; and second, whether airport searches place constitutionally permissible conditions upon the exercise of the right to travel.

72 U.S. Dep't of Transportation, News 103-72, Dec. 5, 1972. As a result of the electronic screening requirement, Eastern Airlines has stopped using the Profile altogether. Letter of Michael J. Fenello, Vice President, Operational Coordination, Eastern Airlines, to The University of Chicago Law Review, Mar. 7, 1973. For the implications of this policy, see text and notes at notes 149-151 infra.

7337 Fed. Reg. 25934 (1972).

74 Airport Operators Council Int'l v. Shafer, 354 F. Supp. 79 (D.D.C. 1973).

75 See discussion of President Nixon's sky-marshal program, note 40 supra.

76 See note 59 supra.

77 The power was vested by virtue of the "acceptable to the Administrator" language of the January 31,1972 order, see text at note 58 supra, and the amendment provisions that followed in late February, see text at note 60 supra.

78 The fourth amendment of the Constitution provides: "The Right of the people to be secure in their persons, houses, papers, and effects, against unreasonable searches and seizures, shall not be violated, and no warrants shall issue, but upon probable cause, supported by Oath or affirmation, and particularly describing the place to be searched, and the person or things to be seized." 


\section{A. Fourth Amendment ${ }^{78}$ Problems}

In Terry v. Ohio, ${ }^{79}$ Chief Justice Warren, speaking for the Court, observed that the fourth amendment's prohibition against unreasonable searches and seizures guarantees to the citizen an "inestimable right of personal security," which "belongs as much to the citizen on the streets of our cities as to the homeowner closeted in his study to dispose of his secret affairs." 80 To ensure that this right of personal security is respected by law enforcement officials, courts have developed a rule requiring the exclusion of evidence seized in violation of the fourth amendment. ${ }^{81}$ With few exceptions, a warrant issued by an impartial third party, usually a judge or magistrate, on the basis of facts sufficient to support an independent finding of probable cause, is required as a condition to the intrusion upon the privacy of an individual's person or possessions. ${ }^{82}$

The Supreme Court has, in practice, determined the reasonableness of a search by looking both to the extent of the intrusion into the privacy of the individual and to the extent of the harm that has necessitated the search. In Katz $v$. United States, ${ }^{83}$ the Court stated that "the Fourth Amendment protects people, not places," and drew a distinction between "what a person knowingly exposes to the public" and "what he seeks to preserve as private, even in an area accessible to the public."84 Yet, where the Court has carved out exceptions to the general fourth amendment rule against warrantless searches, it has found justification in particular exigencies that render the usually strong interest in protecting individual privacy subordinate to the general societal interest in avoiding undue risk of serious harm. ${ }^{85}$

There are three traditional exceptions to the rule against warrant-

79392 U.S. 1 (1968).

$80 I d$, at 8-9.

81 The Court first applied the rule to evidence seized by federal officers in Weeks v. United States, 232 U.S. 383 (1914); in Mapp v. Ohio, 367 U.S. 643 (1961), the Court extended the exclusionary rule to the states.

82 Beck v. Ohio, 379 U.S. 89 (1964).

83389 U.S. 347 (1967).

$84 \mathrm{Yd}$. at 351-52.

85 See, e.g., Carroll v. United States, 267 U.S. 132 (1925); Brinegar v. United States, 338 U.S. 160 (1949) (search of motor vehicle where there is "substantial ground" to believe crime is being or has been committed); Cooper v. California, 386 U.S. 58 (1967) (search of an impounded vehicle pursuant to statute pending forfeiture proceedings where the search is closely related to the reason for the arrest); Warden v. Hayden, 387 U.S. 294 (1967) (search of premises while in "hot pursuit" of suspected felon where suspect had been observed entering the house); United States v. United States Dist. Court, 407 U.S. 297 (1972) (electronic surveillance authorized by the attorney general in cases of foreign espionage). 
less searches. Searches made incident to a lawful arrest have been upheld regardless of the absence of a search warrant ${ }^{86}$ since, in such cases, there is an immediate need to discover potentially harmful objects in the vicinity of the arrestee and to recover evidence that might easily be destroyed. The arrest, however, cannot be made without probable cause, and such cause may not be demonstrated from evidence subsequently seized.87

An individual may also be searched without a warrant if he consents to the search. ${ }^{88}$ The consent must be voluntarily and intelligently given and may not be the result of coercion or duress, actual or implied. ${ }^{89}$ Thus, in Cipres $v$. United States, ${ }^{90}$ the Ninth Circuit said: "Such a waiver cannot be conclusively presumed from a verbal expression of assent. The court must determine ... whether the verbal assent reflected an ... unequivocal election to grant the officer a license which the person knows may be freely and effectively withheld." "g1

The third exception to the warrant requirement was announced by the Court in Terry. Stating that a police officer may, in the course of his duty to investigate possible criminal behavior, approach a person for questioning even though probable cause to make an arrest does not exist, the Court held that, when the officer is "justified in believing that the individual whose suspicious behavior he is investigating at close range is armed and presently dangerous," he may make a limited search of the person, "confined in scope to an intrusion reasonably designed to discover" hidden weapons.92 The Terry exception was, according to the Court, necessary to minimize the risk of harm to police officers in the performance of their investigative duties. ${ }^{93}$

In addition to the incident-to-arrest, consent, and stop-and-frisk exceptions, there are two other less common exceptions: border searches by customs officials, and administrative searches made pursuant to a

86 See, e.g., Chimel v. California, 395 U.S. 752 (1969); United States v. Rabinowitz, 339 U.S. 56 (1950); Trupiano v. United States, 334 U.S. 669 (1948); Harris v. United States, 331 U.S. 145 (1947); cf. Sibron v. New York, 392 U.S. 40 (1968).

87 "It is axiomatic that an incident search may not precede an arrest and serve as part of its justification." Sibron v. New York, 392 U.S. 40, 63 (1968).

88 Zap v. United States, 328 U.S. 624 (1946); cf. Stoner v. California, 376 U.S. 483 (1964); United States v. Como, 340 F.2d 891 (2d Cir. 1965); United States v. Viale, 312 F.2d 595 (2d Cir.), cert. denied, 373 U.S. 903 (1963).

89 See, e.g., Johnson v. Zerbst, 304 U.S. 458 (1938); Cipres v. United States, 343 F.2d 95 (9th Cir. 1965); United States v. Como, 340 F.2d 891 (2d Cir. 1965); United States v. Smith, 308 F.2d 657 (2d Cir. 1962), cert. denied, 372 U.S. 906 (1963); United States v. Bell, 335 F. Supp. 797 (E.D.N.Y. 1971), aff'd, 464 F.2d 667 (2d Cir. 1972).

90343 F.2d 95 (9th Cir. 1965).

91 Id. at 97 (emphasis added).

92392 U.S. 1, 4, 27, 29 (1968).

93 Id. at 23-24. 
state's police power. In 1789, Congress authorized customs officials "to enter any ship or vessel, in which they shall have reason to suspect any goods ... subject to duty shall be concealed; and therein to search for, seize, and secure any such goods . . .."94 While the statute clearly did not require anything like probable cause, it did require some degree of suspicion. In the statute currently authorizing customs searches this requirement has been retained. ${ }^{95}$ Various rationales have been offered to distinguish border searches from searches in other contexts; ${ }^{96}$ nonetheless, the courts have held the fourth amendment applicable to border search cases. As the Ninth Circuit observed, paraphrasing the Supreme Court in Coolidge v. New Hampshire, ${ }^{97}$ "[ $\left.\mathrm{t}\right]$ he word "[border]' is not a talisman in whose presence the fourth amendment fades away and disappears." 98 In United States $v$. Glaziou, ${ }^{99}$ although customs officials were held privileged to conduct searches on a "mere suspicion of possible illegal activity within their jurisdiction,"100 the court added that "border stops and searches, like all stops and searches by public officials, are restricted by the requirement that they be reasonable ..." in the circumstances of each case. ${ }^{101}$ Generally, the courts in border search cases have required an increasing degree of suspicion as the search becomes more intrusive. ${ }^{102}$

94 Act of July 31,1789, ch. $5, \S 24,1$ Stat. 43 (emphasis added).

9519 U.S.C. $\S 482$ (1970): "Any of the officers or persons authorized to board or search vessels may stop, search, and examine . .. any vehicle, beast, or person, on which or whom he or they shall suspect there is merchandise which is subject to duty, or shall have been introduced into the United States in any manner contrary to Law . . ."

98 See Boyd v. United States, 116 U.S. 616, 623 (1886), suggesting that in such a case the government is only searching for what rightfully belongs to it, and that, since the act permitting border searches was passed by the Congress that proposed the Bill of Rights, "it is clear that the members of that body did not regard search and seizure of this kind as 'unreasonable' and they are not embraced within the prohibition of the amendment." One commentator has observed that "the long-standing congressional approval of search of vessels without warrant sanctioned only a hunt for goods entering the United States on which duty had not been paid, not for evidence to be seized domestically for use in a criminal prosecution. J. LANDYNSKI, SEARCH AND SEIZURE AND THE SUPREME COURT: A STUDY IN CONSTITUTIONAL INTERPRETATION 90 (1966). Whatever the historical validity of this remark, it is contrary to the current statute, which directs an officer who discovers contraband to "seize and secure the same for trial." 19 U.S.C. $§ 482$ (1970).

87403 U.S. 443, 461 (1971), holding that stops of automobiles must be supported by specific and articulable facts.

98 United States v. Petersen, No. 72-2133, at 5 (9th Cir. Jan. 18, 1973).

09402 F.2d 8 (2d Cir. 1968).

$100 \mathrm{Id}$. at 12 .

101 Id. at 12-13.

102 Thus, in United States v. Guadalupe-Garza, 421 F.2d 876 (9th Cir. 1970), the court held that "compelling reasons" must appear to justify a strip search. And in Huguez v. United States, 406 F.2d 366, 377-78 (9th Cir. 1969), the court held that there must be at least a real suspicion directed specifically to the person crossing the border for 
In Camara v. Municipal Court ${ }^{103}$ and See $v$. Seattle, ${ }^{104}$ the Supreme Court found that housing code enforcement searches do not fit any of the traditional exceptions to the warrant requirement. It held, therefore, that such searches, when made without warrants, are unreasonable, despite the minimal demands they made upon residents. The Court stated, however, that the probable cause needed to support a code-enforcement warrant need not depend on information particular to each dwelling, but could be based on the agency's appraisal of conditions in an area as a whole, and acknowledged that such warrants need only be sought after the inspector, in nonemergency situations, had attempted to gain entry but had been refused. ${ }^{105}$

In carving out exceptions to the rule against warrantless searches, the Court has consistently attempted to ensure that the individual's interest in privacy remains protected. Even in border search cases, where a lesser standard than probable cause is sufficient to justify some searching, the individual's interest in privacy has been safeguarded by requiring increasing justification as the search becomes more intrusive.

1. The Profile. The "Behavioral Profile," developed in 1969 by the psychology staff of the FAA's Office of Aviation Medicine on the basis of the backgrounds and behavioral characteristics of persons who had attempted hijackings, is a checklist of at least a dozen traits aimed at selecting potential hijackers for further investigation. ${ }^{108}$ It cannot be

an examination of body cavities to comply with the fourth amendment proscription against unreasonable searches. Cf. United States v. Petersen, No. 72-2123 (9th Cir. Jan. 18, 1973); United States v. Weil, 432 F.2d 1320 (9th Cir. 1970); Alexander v. United States, 362 F.2d 379 (9th Cir. 1966), all three of which set forth a standard of "reasonable certainty" that a smuggling offense has taken place where customs agents or other law enforcement persons stop and search a person or vehicle that has recently entered the country and is outside the immediate vicinity of the border area.

103387 U.S. 523 (1967).

104387 U.S. 541 (1967).

105387 U.S. 523, 534-39 (1967).

108 See J. Dailey, supra note 37. Field trials were made in nine cities prior to Eastern Airlines' implementation of the Profile/magnetometer search system in October, 1969. U.S. Dep't of Transportation, News, 69-119, Oct. 15, 1969, at 2. The airlines and the FAA have attempted to keep the contents of the Profile secret, and federal judges, to date, have assisted them. See United States v. Bell, 464 F.2d 667 (2d Cir. 1972); United States v. Lopez, 328 F. Supp. 1077 (E.D.N.Y. 1971), both of which approved disclosure of the elements of the Profile in an in camera proceeding from which the defendant was excluded but in which his counsel was permitted to participate. But see United States v. Clark, No. 72-2147 (2d Cir. Mar. 8, 1973), holding it an unconstitutional denial of a defendant's sixth amendment right of confrontation to exclude him from any part of a suppression hearing except that which specifically involved disclosure of elements of the Profile. Nonetheless, some of the details have been publicized, and it is doubtful that the remainder can be guarded indefinitely. One columnist states that the Profile identifies males, between the ages of fifteen and fifty-five, who are traveling alone, purchase a one-way ticket, and pay in cash. 
argued that application of the Profile intrudes, in the usual fourth amendment sense, upon the normally expected privacy of the individual: ${ }^{107}$ its use does not involve restraint of the individual, and it measures only those characteristics that the traveler has exposed either to general public view or to the airline when he purchases a ticket. The constitutional question presented by use of the Profile is, instead, whether it can be used to support a finding of probable cause to search a traveler or to justify a more limited intrusion-scanning with a magnetometer.

In Terry v. Ohio, ${ }^{108}$ the Supreme Court authorized a stop when there are "specific and articulable facts" sufficient to support a reasonable belief that the action is warranted, ${ }^{109}$ and held a frisk of the suspect permissible when the officer could reasonably believe that the suspect was armed and presently dangerous. ${ }^{110}$ Because of its unreliability, the Profile cannot be said to provide specific and articulable facts indicating that a selectee is a hijacker. Although the Profile is revised when new data become available, ${ }^{111}$ there have only been 159 attempted hijackings of United States aircraft, ${ }^{112}$ involving only 218 individuals; ${ }^{113}$ many hijackers are currently fugitives in other lands, some were killed, others used aliases and their true identities remain unknown. ${ }^{114}$ It

Killian, Profile of a Potential Skyjacker, Chicago Tribune, Dec. 3, 1972, \& I-A, at 5 col. 3. See also United States v. Riggs, No. 72-2181 (2d Cir. Feb. 15, 1973), indicating that the Profile was met by the defendant, a young black female accompanied by two males, who were wearing "a brilliant orange coat and carrying no luggage," and who bought three one-way tickets for which she paid cash produced from a brown paper bag.

In fact, the Profile is a method of exclusion of passengers as hijacker suspects; it is used to clear individuals wishing to board airplanes. As developed, the elements of the Profile were kept simple and a passenger would have to fit all of them to be considered a suspect. But the FAA claimed to have a large number of characteristics "in reserve" that could be added to the Profile, in which case a passenger might not have to meet all the elements to become a suspect. FAA TASK Force on Deterrence of Air Piracy, U.S. Efrorts to Deter FIIJACKINGS 28-81 (1970).

107 Note, supra note 7, at 1052.

108392 U.S. 1 (1968).

100392 U.S. at 21-22. The facts are to be measured against an objective, reasonable man standard, not by the subjective impressions of the particular officer: "Anything less would invite intrusions upon constitutionally guaranteed rights based on nothing more substantial than inarticulate hunches . . . ." Id.

110 Id. at 24.

111 See J. Dailey, supra note 37.

112 Chronology of U.S. Hijackings, stpra note 15.

113 Id; Lindsey, 218 Persons Involved in 159 U.S. Hijackings Since 1961, FAA Says, N.Y. Times, Nov. 16, 1972, at 3, col. 1.

114 The FAA reports that, of the 218 persons involved in 159 domestic hijackings, 124 are fugitives, forty-four were convicted in the United States, five were convicted abroad, four were acquitted, charges against fifteen were dropped, five were killed during the attempt, three committed suicide, and sixteen are in mental institutions. Cases are pending 
seems highly unlikely that a statistically reliable list of a dozen characteristics could be distilled from such a limited sample.115 Even if such a list could be devised, the circumstances of its application cast additional doubts on its reliability. Airline agents, who lack special training ${ }^{116}$ and apply the Profile at ticket counters and boarding gates, have only a brief opportunity to observe passengers and must perform other duties at the same time. ${ }^{117}$ In these circumstances, the Profile seems no more likely to identify hijackers or other criminals than a mere random selection of 0.5 percent of all air travelers - the percentage selected by the Profile. ${ }^{118}$ In United States $v$. Lopez, ${ }^{119}$ Judge Weinstein noted that, of those passengers who fit the Profile, only about one-third, or 0.1 percent of all passengers, "fail" the magnetometer, cannot satisfy the U.S. Marshal's interrogation, and are frisked. ${ }^{120}$ Of those frisked, a weapon is found in about 6 percent of the cases. ${ }^{121}$ Thus, only about 2 percent of the Profile-selectees-0.01 percent of all passengers-turn out to possess a weapon. At this rather low degree of specificity, it

against the remainder. Lindsey, supra note 113. For an individual accounting, see FAA, Office of Air Transportation Security, Current Legal Status of Hijackers, Dec. 1, 1972.

115 In order to predict at a high level of certainty the effect on one dependent variable (hijacking) of variation in one independent variable requires approximately thirty observations. M. EZZRIEL, METHODS OF CORRELATION ANALXSIS 22 (2d ed. 1941). Approximately 100 observations are required to estimate the effect of two independent variables, id. at 186, and the number of observations required to maintain the same degree of certainty increases logarithmically with the addition of further independent variables. Since no more than 218 hijackers could have been observed for the sample, see note 114 supra, and the Profile allegedly contains more than twelve independent variables, see text and notes at notes 38,106 supra, the predictive ability of the Profile is miniscule.

There probably is some predictive value in the Profile, however. Many of the variables are undoubtedly covariate, so there are fewer than twelve effective variables. Each variable has a limited range of values (sex, for example, has only two), further reducing the error. Finally, the sample of "hijackers" is not a random cross section of "air travelers," and selectivity in the sample can increase the predictive effect. Even these three factors do not make the Profile highly reliable, however. It seems safe to assert that, since selectees are a small subset of travelers, and most travelers are nonhijackers, and the Profile is not highly reliable, most hijackers are not selectees and the vast majority of selectees are not hijackers.

116 Airline personnel working in terminals were simply trained to be aware of the elements of the Profile. At Eastern Airlines they were themselves screened for any personality traits that might work against their impartial application of the Profile. Fenello, supra note 6 , at 31 .

117 The difficulty of applying the Profile objectively is compounded by the fact that, for security purposes, its details are never written down, but are passed on orally from supervisor to agent. Id.; see SENATE CoMm. on CoMmerce, REPort on S. 39, 93d Cong., Ist Sess. 8, 9 (Comm. Print 1973), expressing reservations as to the ability of airline employees to effectively and objectively apply the Profile.

118 Fenello, supra note 6, at 31 .

119328 F. Supp. 1077 (E.D.N.Y. 1971).

$120 \mathrm{Id}$. at 1084, 1097.

$121 \mathrm{Id}$. 
seems logical to expect that, after magnetometer screening and interrogation by the marshal, 2 percent of random selectees would also possess a weapon. In fact, the Profile has thus far proved more proficient at selecting persons carrying illegal drugs than it has at identifying possible hijackers. ${ }^{122}$

In Lopez, Judge Weinstein argued that the Profile/magnetometer in combination was sufficiently reliable to justify questioning and, if necessary, a frisk for weapons. Attention was focused not on the validity of the Profile itself, but rather on the frisk that resulted when the Profile, magnetometer, and questioning by a law enforcement officer combined to raise suspicion as to a particular individual. Noting the statistics cited above and observing that only a miniscule percentage of passengers are detained for questioning, the court balanced the limited nature of a frisk against the harm of hijacking: "In light of the circumstances, a $6 \%$ danger of arms [among those frisked] sufficed to justify a frisk." 123 The court added that the "procedure, as designed, operates on purely objective criteria independent of race, color, or creed."124

The opinion in Lopez, ${ }^{125}$ assumes that a 6 percent likelihood of finding weapons on those frisked is sufficient, given the exigencies of hijacking, to justify the intrusion. But this assumption is vitiated if a

122 See Air Piracy Scoreboard (January, 1973), enclosed with Letter from V.L. Krohn, supra note 59, indicating that nearly twice as many arrests have been made for drug offenses as for weapons offenses. During a twenty-two month period through the fall of 1972, weapons offenses accounted for less than 20 percent of all airport arrests, drug arrests amounted to about one-third, and the balance was for illegal entry and other crimes. Lindsey, Skyjacking Screening Cuts Other Arrests at Airports, N.Y. Times, Apr. 8, 1973, $\$ 5$, at 25, col. 6. The article stated that since mandatory screening began in January, 1973, the number of airport arrests has declined.

$123328 \mathrm{~F}$. Supp. at 1097. The particular circumstances to which Judge Weinstein was referring appear to be the prevalence and nature of hijacking:

Mere statistical information such as that generated in this case does not, by itself, justify "frisks." If, for example, reliable statistics were available that in a given community one person in fifteen $(6 \%)$ regularly carried concealed weapons the police would not be justified in arbitrarily stopping and frisking anyone on the street. Such harassment by police without more objective evidence of criminal activity or a legitimate investigative purpose is proscribed by the Fourth Amendment.... The Court is charged with balancing the competing interests of the individual and the society in each case presented.

Id. at 1097-98.

124 Id. at 1097.

125 Unfortunately, the opinion is entirely dicta, since the court found that the airline employee, in applying the Profile to the defendant, had eliminated one criterion from the official FAA Profile and included two additional categories. One of the characteristics added introduced an ethnic element for which there was no experimental basis and the second "called for an act of individual judgment" by the employee, thus destroying what the court termed "the essential neutrality and objectivity of the approved profile," and rendering the screening unconstitutional. $I d$. at 1101 . 
frisk of a random selection of 0.1 percent of all passengers-the percentage selected by the screening system to be frisked-produces comparable results. In addition, the decision that the Profile/magnetometer combination satisfies the Terry test of specific-and-articulable facts assumes, implicitly, a crucial step in the search procedure-that the Profile justifies the intrusion inherent in the magnetometer scan. Prior to the promulgation of the FAA's December rules, all passengers were required to walk through the magnetometer, but only Profile selectees were stopped upon activation of the device. If the magnetometer is itself a stop, it is justifiable only if the Profile satisfies the specific-andarticulable facts standard of Terry.

Terry requires, however, only that the specific, articulable facts, "taken together with rational inferences from those facts," reasonably warrant the actual intrusion made. ${ }^{126}$ If, therefore, magnetometer screening can be considered less intrusive than the investigative stop in Terry, the facts necessary to justify it may be less specific and articulable than those necessary to justify a stop. ${ }^{127}$ In Terry, the officer who made the stop was a veteran policeman, experienced in investigating criminal behavior; when he stopped the suspects, he had a particularized notion of the criminal actions in which they might be engaging. ${ }^{128}$ The FAA, in contrast, regarded the apprehension of drug offenders that resulted from applying the Profile as an unexpected bonus. ${ }^{129}$ Of course, if, because of the small percentage of selectees who have been found to possess weapons or other hijacking tools, the Profile qualifies as a showing of specific and articulable facts, then the unexpected drug offender dividend does not make use of the Profile improper.

It seems appropriate to conclude that the magnetometer is not a stop; it is a more limited step in the ascending chain of justification leading to a Terry-type stop-and-frisk. If, however, the magnetometer is a search, however limited, it must have its own justification. Though the Profile does not support a finding of probable cause, or even specific-and-articulable facts justifying a stop, it may give rise to a suspicion sufficient to justify the limited intrusion that magnetometer scanning entails.

\section{The Magnetometer. The magnetometer is an electronic device}

126392 U.S. at 21.

127 "Because one variable is the degree of imposition on the individual . . . less evidence is needed ... when the consequences for the individual are less serious." LaFave, "Street Encounters" and the Constitution: Terry, Sibron, Peters, and Beyond, 67 Micr. L. REv. 40, 54 (1968).

128392 U.S. at 23.

129 U.S. Dep't of Transportation, News, 70-41, May 6, 1970, at 1. 
that can be tuned to detect various amounts of ferrous metal. ${ }^{130}$ It cannot, however, distinguish between a concealed weapon and an "innocent" iron or steel item of like mass, nor can it detect weapons made from metal alloys that do not disturb the earth's gravitational field.131 The largest manufacturer of the devices recommends that, for optimum utility, they be tuned to detect an amount of ferrous metal equivalent to that in a .32 caliber handgun. ${ }^{132}$ Since half of all air travelers normally carry this much ferrous metal ${ }^{133}$ they are identified by the magnetometer as potential carriers of .32 caliber (or larger) weapons.

While the magnetometer does not involve any physical intrusion upon the individual or his property, it nonetheless constitutes a search in the constitutional sense. In Katz $v$. United States, ${ }^{134}$ the Supreme Court rejected the government's contention that placing an electronic listening device on the outside of a public phone booth was not violative of the fourth amendment, and overruled two former cases holding that only physical considerations were relevant to the invasion of privacy question. ${ }^{135}$

The bugging device in $K a t z$ and the magnetometer differ in the extent of the intrusion upon the individual's privacy. The magnetometer involves a minimal intrusion, since the traveler must simply walk through the device; it is not intrinsically offensive, since there is no restraint or exposure and, even during the period prior to the December 5 th rules, everyone seeking to board was subjected to identical treatment, even though only Profile selectees were actually monitored. More sophisticated devices using $\mathrm{x}$-rays or fluoroscopy ${ }^{\mathbf{1 3 6}}$ would intrude more significantly since they reveal more intimate detail. Thus, holding that the magnetometer scan is a search is advantageous for two reasons. First, it is clearly compatible with Katz. Second, it would not require courts to make qualitative, search/no search distinctions as more intrusive scanners were put into use, but would permit

130 See Wahl, How Science Will Foil the Skyjackers, 97 Popular MEchanics 58 (Nov. 1970 ), describing the magnetometer and how it operates.

131 Id. at 59.

132 See Letter and Ground Deterrence of Aircraft Hijacking, AN 107-2, at 4, from M.M. Schwartz, President, Infinetics, Inc., to The University of Chicago Law Review, Jan. 3, 1973. Mr. Schwartz estimates that his firm supplies "perhaps $98 \%$ " of the world's metal detection devices.

138 United States v. Lopez, 328 F. Supp. 1077, 1086, 1097 (E.D.N.Y. 1971); Wahl, supra note 130 , at 59 .

134389 U.S. 347 (1967); see text at notes 83-84 supra.

135389 U.S. at 353 . The two prior cases were Olmstead v. United States, 277 U.S. 438 (1928) and Goldman v. United States, 316 U.S. 129 (1942).

136 See Fenello, supra note 6, at 39-40; Wahl, supra note 130, at 123. 
them to distinguish quantitatively in terms of the extent of the intrusion.

To date, the courts have given only limited consideration to the fourth amendment problems raised by magnetometer scanning. In United States $v$. Epperson, ${ }^{137}$ the court, upholding a magnetometer search, said that: " $[t]$ he search for the sole purpose of discovering weapons and preventing air piracy, and not for the purpose of discovering weapons and pre-criminal events, fully justified the minimal invasion of personal privacy by magnetometer. The use of the device, unlike frisking, cannot possibly be 'an annoying, frightening, and perhaps humiliating experience." "188 The court found an "overwhelming governmental interest" in preventing hijackings, and found that this interest justified the routine subjection of passengers to magnetometer searches. ${ }^{139}$ In United States v. Slocum, ${ }^{140}$ the court cited Epperson in sustaining a magnetometer search, adding that "[r]easonableness is the ultimate standard" in determining whether fourth amendment guarantees were violated..$^{141}$ Both the Slocum and Epperson courts, however, seem to have resolved the issue of reasonableness by giving conclusive weight to the government's interest in protecting air passengers from the "potential consequences" of hijacking, ${ }^{142}$ with little consideration to the individual's fourth amendment interest in freedom from intrusion into his personal privacy or to the Terry decision and its relevance to airport searches..$^{143}$

In Terry, Camara, and the border search cases, it was held that though serious potential consequences may contribute to justify a warrantless search, the search must be narrowly directed to the danger it is intended to avert, and the presence of the danger must be indicated by specific and articulable facts. Thus, contrary to the implications of Epperson and Slocum, the "overwhelming government inter-

137454 F.2d 769 (4th Cir. 1972).

$138 \mathrm{Id}$. at 771 . The distinction between "discovering weapons and preventing air piracy" on the one hand, and "discovering weapons and pre-criminal events" on the other, is illusory. All manner of criminal activity is being sought out and punished as a result of airport searches. See text and note at note 122 supra.

139454 F.2d at 771 .

140464 F.2d 1180 (3d Cir. 1972).

141 Id. at 1182.

142 In Slocum, Chief Judge Seitz stated: "[W]e conclude that within the context of a potential hijacking the necessarily limited search accomplished by use of the magnetometer per se is justified by a reasonable governmental interest in protecting national air commerce. Under the circumstances suggesting a potential for the serious consequences incident to hijackings, employment of the magnetometer does not violate the 4th Amendment." Id. at 1182 .

143 In Slocum, the court did not mention Terry. The sole hint of consideration of individual rights was the reference to "the necessarily limited search." $I d$. 
est" in preventing hijacking does not, by itself, justify intrusion; the interest must be weighed against fourth amendment values of privacy and personal security, and there must be an articulable apprehension of danger in each individual case.

The use of the magnetometer involves less of an intrusion and restraint than the stop-and-frisk in Terry. But since only a very small number of those selected by the Profile turn out to be committing any offense, ${ }^{144}$ it cannot be contended that prior to the application of the magnetometer, specific and articulable facts exist indicating possible criminal behavior and that a "reasonable belief" exists that the suspect is armed and dangerous. ${ }^{145}$ Nonetheless, the principle of Terry, Camara and the border search cases permit the magnetometer scan so long as there is a correspondence between the extent of the intrusion and its proferred justification. ${ }^{146}$ It seems consistent with those cases, therefore, to conclude that the suspicion created by the Profile warrants the limited diversion of the individual and marginal intrusion on his privacy that use of the magnetometer requires.

If, however, the magnetometer search is justified only on the basis of the Profile, only Profile selectees should be subjected to it. Under the December 5th rules all passengers are required to pass through the magnetometer, ${ }^{147}$ and the airlines apparently have discarded the Profile as a tool for determining who will be monitored and detained upon activation of the device. ${ }^{148}$ This makes the magnetometer a dragnet screening device; as such, it seems clearly unconstitutional. ${ }^{148}$

To deal with this problem, the airlines could simply resurrect the Profile. They could request-but not require-all or some random number of nonselectees to pass through the magnetometer, thus preserving the Profile's secrecy. In the unlikely event that a nonselectee objected, he could be allowed unobtrusively to board without passing through. If a selectee objected, the airline agent could inform the traveler quietly that he must pass through the magnetometer if he

144 Altogether, only about six thousand airport arrests have been made. Lindsey, Ruling Restricts Airport Searches, N.Y. Times, Dec. 10, 1972, § 1, at 29, col. I.

146 However, this was, in effect, the assertion made by Chief Judge Seitz in Slocum, where he argued that use of the magnetometer, unsupported by any justification, was permitted in view of the compelling governmental interest in preventing hijacking.

140 See note 127 sipra.

147 U.S. Dep't of Transportation, News, 103-72, Dec. 5, 1972, at 1.

148 Eastern Airlines claims that it no longer uses the Profile and relies strictly on the magnetometer and mandatory luggage search. Letter from Michael J. Fenello, supra note 72. Previously, though all passengers were required to walk through the magnetometer, only Profile selectees were actually monitored.

149 The same problems render the carry-on luggage search invalid. See text at notes 152-8 infra. 
wants to board. Assuming that the Profile is statistically reliable, this procedure would at once avoid the constitutional objections to universal, mandatory magnetometer searches, maintain the secrecy of the Profile, avoid the delay resulting from questioning and possibly frisking each of the many passengers who activate the magnetometer, ${ }^{150}$ and involve only a slight change in present airline procedures..$^{151}$

Although no court to date has had any difficulty using conventional fourth amendment analysis to find that the combination of Profile, magnetometer, and interrogation justifies a limited Terry-type search for weapons, the analysis of constitutional principles involved in reaching that result has been inadequate. The validity of the Profile has not been subjected to adequate analysis-an analysis that might well prove fatal. More important, given the requirement of the December 5th rules that all passengers be screened by magnetometers, no court has dealt with the question of the degree of specific and articulable facts required to support use of the magnetometer. Only by confronting these problems can any meaningful conclusion be drawn as to the constitutionality of airport searches.

3. The Search of Carry-On Luggage. No court has yet considered the requirement, included in the December 5 th rules, that all airlines conduct a search of the contents of all passengers' carry-on luggage prior to boarding. There can be no doubt that the carry-on luggage inspection is a search, nor can the extent of the intrusion be considered minimal. The contents of a person's briefcase or other personal belongings clearly represent items toward which he may harbor a reasonable "expectation of privacy."152 Yet carry-on luggage is subjected to search even though its owner in no way raises any suspicion of being a potential hijacker. In 1969, the peak year in United States hijacking, there were 150 million domestic passenger emplanements ${ }^{153}$ but only forty attempted hijackings; ${ }^{154}$ assuming that two hijackers were involved in each attempt, ${ }^{155}$ only about one of every two million passengers was a

160 Approximately 50 percent of all passengers activate the magnetometer. See note 133 supra.

151 The FAA, which imposed the dragnet magnetometer screening requirement by virtue of its rulemaking authority, see text and notes at notes 70-72 supra, could similarly reinstate the Profile.

152 Katz v. United States, 389 U.S. 347, 361 (1967) (Harlan, J., concurring).

153 U.S. DEP'T OF TRANSPORTatzon, FAA STATISTICAL HANDBOOK OF AvIATION 139 (1970).

154 Hijacking Attempts on U.S. Registered Aircraft, supra note 2.

155 This is, in fact, a rather generous assumption. See House CoMm. on Foreign Afrairs, supra note 18, at 13, indicating that sixty-five persons had been involved in thirty-eight attempted hijackings to Cuba between 1961 and 1968. In U.S. hijacking history, 213 persons have been involved in 159 attempts. See text at notes 112-113 supra. 
hijacker. Nonetheless, the carry-on luggage search assumes that every air traveler is a hijacking suspect.

The carry-on luggage search falls within none of the exceptions to the rule against warrantless searches thus far recognized by the Court. It is not made incident to a lawful arrest, nor can it be analogized to the frisk for weapons in Terry in which the officer had reasonable grounds to believe that the suspect was armed and dangerous. Furthermore, neither the border search nor the Camara cases support the constitutionality of the carry-on luggage search. An airport boarding gate is not an international boundary and, in any case, border searches require at least a suspicion of wrongdoing-a suspicion totally absent in the dragnet carry-on luggage search. Although Camara authorized area warrants based on an official's appraisal of conditions in an area as a whole, it nonetheless requires some showing "particularly describing the place to be searched" and what the official was looking for. It may be argued that because the passenger, unlike the residential dwelling in Camara, is mobile, the warrant requirement should be waived. But even if this is so, there is no reason to require any lower standard than the suspicion required in border search cases-a standard that cannot be met by a dragnet search.

It has been argued that, because one hijacker can endanger numerous people and millions of dollars worth of machinery, no particularized grounds for a carry-on luggage search should be required. ${ }^{156}$ The aggregate cost of hijacking, in terms of loss of life, property damage, and monetary cost, is, however, far less than the cost of other serious, and many not-so-serious crimes. ${ }^{157}$ The weakness of the "great danger"

156 See United States v. Bell, 464 F.2d 667 (2d Gir. 1972), in which Judge Friendly, in a concurring opinion, argued that "the danger alone meets the test of reasonableness, so long as the search is conducted in good faith for the purpose of preventing hijacking or like damage and with reasonable scope and the passenger has been given advance notice of his liability to such a search so that he can avoid it by choosing not to travel by air." Id. at 675. Judge Mansfield, concurring in Bell, argued that, if danger alone justified searching, "the sharp increase in the rate of serious crimes in our major cities could equally be used to justify similar searches of persons or homes in high crime areas . . ." Id. at 676.

157 In 1970, for example, there were over 1.7 million cases of larceny over $\$ 50$, and over 900,000 cases of auto theft. Comm. For Economic Development, Reducing CRIME AND Assuring Jusmce 80 (1972). Taking only these two common crimes against property, the cost far exceeds the costs of hijacking estimated in part III of this comment, infra. Even in terms of cost of human lives, there is no comparison between hijacking, which, in its entire history, has only touched about 50,000 passengers and 5,000 crew members, according to one source, see Friedlander, supra note 5 (the estimate seems quite high), and homicide, of which there were over 15,000 instances in the U.S. in 1970 alone, CoMM. FOR ECONOMIC Devecorment, supra, at 80. In the history of U.S. hijacking attempts, a total of twelve persons (including six hijackers) have been killed and nineteen persons have been injured. Trilling, Total Airport Security Systems, Remarks before the Air Transport Security Panel, 1973 Sociey of Automotive Engineers National Air Transportation Meeting, Miami, 
argument becomes clear when extended to its logical extreme. An atomic bomb smuggled into the city of Chicago would pose a tremendous threat to people and property. Under the "great danger" argument, the fact that no one has ever attempted to detonate an atomic bomb in Chicago is irrelevant, since the danger-destruction of the city or a large part of it-is so great that if it happened even once it would be a catastrophe of incredible proportion. Yet, if danger alone were sufficient to justify an exception to the rule against warrantless searches, the police could set roadblocks on every road leading into cities to search cars for bombs.

The hijacking problem differs, of course, from the bomb or streetcrime examples since the number of people searched is limited to those who wish to board a plane. But this argument is really one of degree: the street-crime analogy could be narrowed to a single precinct, ward, or block. In Lankford $v$. Gelston, ${ }^{158}$ the fourth circuit held violative of the fourth amendment a police search, conducted over a nineteen-day period, of three hundred dwellings in a Baltimore community. The police, looking for two armed robbers who had been traced to the general community, searched private homes on the basis of unverified anonymous tips. While it is perhaps more aesthetically pleasing to be searched by a courteous guard at an airline boarding gate than to be awakened at night by the police, a similar invasion of privacy is present in both cases. And arguably, the searches in Lankford were more justifiable since they were at least based on some small, articulable ground for suspicion and were confined to a small group. Since there is neither probable cause, specific and articulable facts, nor even "border search" or "magnetometer-type" suspicion in the carry-on luggage case, such searches seem constitutionally impermissible, at least in the absence of valid consent.

4. Consent Problems. In Lopez ${ }^{159}$ and United States $v$. Meulener, ${ }_{2}^{100}$ the district courts rejected the government's contention that because notices are placed in boarding areas and on the passengers' tickets warning that persons and belongings are subject to search, attempting to board an aircraft constitutes implied consent to an airport search. In

Fla., April 24, 1973, at 7. Dr. Trilling notes that at least 183 passengers and twenty-seven crew members have been killed aboard U.S. registered aircraft as a result of bomb sabotage incidents; worldwide since 1949, the toll has been 535 people killed. $I d$.

No one would suggest that the high incidence of street crime justifies dragnet searches of pedestrians, even in "high crime" areas. See United States v. Mallides, No. 72-1898 (9th Cir. Jan. 22, 1973), at n. 3. See also note 123 supra.

158364 F.2d 197 (4th Gir. 1966).

159328 F. Supp. 1077, 1093 (E.D.N.Y. 1971).

160351 F. Supp. 1284 (C.D. Cal. 1972). 
Meulener, the court stated that such notices were insufficient to meet the knowing waiver standard of Cipres. ${ }^{161}$ The court held that a passenger who fits the Profile and activates the magnetometer may constitutionally be searched only if he is advised that he has the right to refuse to be searched if he consents not to board the aircraft. ${ }^{102}$ Since the defendant in Meulener had opened his suitcase containing narcotics "at a time when he was not free to leave or to avoid the search," the court held that the search was inherently coercive. ${ }^{163}$

Neither the Meulener nor the Lopez court considered the argument that, since carry-on luggage will not be searched if checked and stowed in the belly of the aircraft, ${ }^{164}$ a person implicitly consents to have his carry-on luggage searched when he attempts to board. If the courts accepted this argument, air travelers would be required to forego their fourth amendment rights if they prefer to maintain personal control over their property during flight. On the other hand, the cost of retaining fourth amendment rights is small-the passenger is deprived of his property only for the short time he is on the aircraft-and the need, prevention of hijacking, is great. If contraband begins turning up in carry-on luggage subjected to the dragnet search, this argument may receive considerable attention. ${ }^{165}$

Indeed, the argument might be reasonable if no alternative to dragnet searches were available. In fact, however, holding the carry-on search unconstitutional and requiring justification for magnetometer

101 Id. at $1287-88$.

162 Id. at 1289. The court stated that neither the defendant's person nor his suitcase could be searched if he chose not to board. With respect to a frisk of the defendant's person, this statement seems questionable. The court said that the governmental interest justifying a frisk in the airport case was protection of the passengers and crew on the airplane. Id. But it seems reasonable that, when a marshal informs a selectee that he may not board, the marshal himself may be physically endangered, thus bringing into play the rationale of Terry and justifying a frisk whether or not the selectee desires to board.

103 Id. at 1288.

164 But see United States v. Burton, 351 F. Supp. 1372 (W.D. Mo. 1972), in which the court, in a bench trial, found the defendant guilty of delivery of a firearm for transportation in interstate commerce without proper notice to the carrier. An airline employee discovered the firearm in the defendant's suitcase, which had been checked on the flight that the defendant was preparing to board. In an earlier suppression hearing the court held the search of the defendant's suitcase was valid. United States v. Burton, 341 F. Supp. 302 (W.D. Mo. 1972). The arline employee had made the search on his own initiative, after observing that the defendant (who, incidentally, had purchased a round trip ticket) met the Profile, and that one of his bags-the one ultimately found to contain the firearm-was heavy and the weight unevenly distributed. After opening the suitcase and finding the firearm, the agent called a U.S. marshal, who arrested the defendant. Id. at 304-05.

165 But see Lindsey, supra note 122, to the effect that arrests have declined since implementation of the December 5th rules, indicating that passengers are aware of airport searches and are stowing items in their checked luggage to avoid searches. 
screening need not mean that a hijacker could secret a weapon in a briefcase or on his person and avoid detection. Profile selectees could be required to walk through the magnetometer with their carry-on luggage in hand..$^{186}$ If a selectee activated the magnetometer, he could be relieved of his carry-on luggage and asked to walk through again. If he activated the device a second time, grounds would exist to request identification, question the selectee, and, if necessary, perform a frisk. In such a case, the selectee's hand luggage could be separately screened, perhaps with a hand-held device, to determine if it, too, might contain weapons. If the hand-held device indicated that the hand luggage contained a high level of ferrous metal, or if the selectee, without his hand luggage, did not activate the magnetometer, grounds would exist for questioning the selectee about the contents of his hand luggage. If the selectee could not explain why his hand luggage had activated the magnetometer, grounds would exist for a search. ${ }^{167}$ This alternative procedure $^{168}$ would both serve the deterrent and detection functions

166 Under the FAA's December 5th rules, as implemented by the airlines, only the passenger walks through the magnetometer; his luggage is handed to him on the other side by the attendant performing the carry-on search. Thus, unless the attendant actually sees a weapon in the course of the carry-on search, it will escape detection.

167 The amount of metal in the frame and locks of many attache cases might trigger the magnetometer, effectively giving grounds to search every briefcase-bearing passenger. This problem could be solved by screening such cases separately with a magnetometer tuned to pick up metal levels in excess of those contained in their frames. Alternatively, magnetometer-watchers could be supplied with a list of the most popular attache cases on the market and their ferrous metal levels when empty; when the magnetometer indicated a metal level in excess of the stated level for a particular model case, grounds would exist for inquiry into the nature of its contents.

168 With one small but significant exception, this is the sysem proposed by S. 39, 93d Cong., 1st Sess., which has passed the Senate and now awaits consideration by the House. As explained in the committee report, CoMm. ON CoMmERce, REPORT ON S. 39, 93d Cong., Ist Sess. 9 (Comm. Print 1973), the Profile would not be used to identify selectees. Rather, all passengers would be required to pass through the magnetometer. The bill adopts this approach apparently because of the committee's belief that the Profile "has not been totally effective in safeguarding our air transportation system from attack." Id. at 8 . The committee report states that "occasions have occurred in which, during the pressures of boarding, agents have inadvertently not applied the profile to all passengers, or have applied it incorrectly." Id; see text at note 117 , criticizing the Profile for this reason. The committee's solution, however, discards the baby with the bath. The problem of ineffective or discriminatory Profile screening could be corrected by court decisions suppres. sing evidence when the airlines did not have one agent present at the boarding gate who had the sole job of applying the Profile. Of course, this would still not legalize the search if, as a statistical matter, the Profile is no better than random selection. But it does achieve two important results. First, it provides a basis for magnetometer screening, which, on a dragnet basis, is clearly unconstitutional. Second, it greatly minimizes the extent of the screening task. Under the December 5 th rules and S. 39, all passengers must be monitored by magnetometer and detained if they activate the device. Since about half of all pas- 
of the present system and, at the same time, avoid the tension between the present system and fourth amendment rights. ${ }^{169}$

\section{B. Right to Travel Problems}

Even absent right to privacy considerations, airport searches, as governmentally imposed burdens on travelers, are constitutionally suspect. In a series of cases ${ }^{170}$ the Supreme Court has protected the right of persons to travel from state to state and abroad, holding that any burden on the right to travel is subject to close scrutiny and must be "necessary to promote a compelling government interest."171 Recently, however, in Evansoille-Vanderburgh Airport Authority District $v$. Delta Airlines, ${ }^{\mathbf{1 7 2}}$ the Court held that a nondiscriminatory airport fee of one dollar per passenger was not a burden in the constitutional sense on the right to travel; since the revenue was used to build and maintain airport facilities, the fees promoted rather than discouraged travel. Instead of applying the strict scrutiny standard, the Court looked to whether the fee charged was reasonably proportionate to the benefits received. It may be argued, therefore, that if the burdens imposed on air travelers by airport searches are reasonably related to the

sengers activate the magnetometer, this task is monumental. Since only 0.5 percent fit the Profile, the screening task and the attendant delay would be minimal.

In addition, $S .39$ would permit a passenger who appears to have a weapon on his person to avoid a frisk by declining to board the aircraft. This is the same position taken by Judge Ferguson in Meulener, see note 162 supra, and it shares the same problem: if a selectee may have weapons on his person, he may be sufficiently dangerous to justify the officer in the belief that a frisk is necessary for the protection of himself and those nearby.

169 The courts have yet to consider the argument that implied consent to an airport search exists because alternative means of transportation are available. The argument was alluded to in United States v. Bell, 464 F.2d 667, at 675 (2d Cir. 1972) (Friendly, J. concurring), quoted at note 156 supra. It is marginal at best; at worst, it collides squarely with the individual's right to travel, since there may be no satisfactory alternative means of transportation available to one desiring to travel any substantial distance.

170 See, e.g., Dunn v. Blumstein, 405 U.S. 330 (1972); Graham v. Richardson, 403 U.S. 365 (1971); Oregon v. Mitchell, 400 U.S. 112, 237, 285 (1970) (concurring opinions of Brennan and Stewart, JJ.); Shapiro v. Thompson, 394 U.S. 618 (1969); Aptheker v. Secretary of State, 378 U.S. 500 (1964); Edwards v. California, 314 U.S. 160 (1941); Truax v. Raich, 239 U.S. 33 (1915). See generally Z. Chafee, Three Human Righrs in the Constritution of 1787, at 162 ff. (1956); Boudin, The Constitutional Right to Travel, 56 CoLUM. L. REv. 47 (1956); Vestal, Freedom of Movement, 41 IowA L. REv. 6 (1955); Note, Interstate Migration and Personal Liberty, 40 CoLUM. L. REv. 1032 (1940); Comment, The Right to Travel -Its Protection and Application Under the Constitution, 40 U. Mrssourr-Kansas CrTY L. REv. 66 (1971).

171 Dunn v. Blumstein, 405 U.S. 330, 389, (1972), quoting Shapiro v. Thompson, 394 U.S. 618,684 (1969) (emphasis in the original).

172405 U.S. 707 (1972). 
increased security that they receive, the searches are not an impermissible burden on the right to travel.

If, however, air travelers must forego fourth amendment protection against unreasonable searches and seizures as a condition of boarding, the present airport search procedure places a double burden on constitutionally protected rights: the traveler is allowed to exercise his right to travel only if he consents to a search that is constitutionally impermissible. ${ }^{173}$ Under these circumstances, the burden on travel should be measured by the strict scrutiny standard, and should be justified only by a compelling government interest. ${ }^{174}$ Both the Lopez and Muelener courts held that no such interest compels the present procedure. ${ }^{175}$ It is not enough that the procedure be reasonable; it must be the least burdensome means of attaining the end of air safety. Since the carry-on luggage search is, as presently conducted, largely ineffective ${ }^{176}$ and since a less burdensome alternative for screening hand luggage exists, ${ }^{177}$ Lopez and Meulener seem correct in concluding that air travel may not be conditioned upon consent to the carry-on search.

\section{Summary}

The airport search procedure can best be viewed as an ascending spiral of intrusions, each based upon and more intrusive than its predecessor. The Profile is the key element in the procedure since, while not itself a search, it may provide the limited justification necessary for the slightly intrusive magnetometer scan. Under careful consideration, the invalidity ${ }^{178}$ of the Profile may render it insufficient to justify even this narrow intrusion. If, however, Profile identification is deemed sufficiently valid, it may serve as the starting point for a search procedure including magnetometer scan, frisk for weapons and, only then, inspec-

173 See Aptheker v. Secretary of State, 378 U.S. 500 (1964), holding that the denial of passports to members of the Communist party burdened both free speech and the right to travel.

174 See note 171 supra; cf. Aptheker v. Secretary of State, 378 U.S. at 520 (Douglas, J., concurring).

175 Moreover, "the government ... [cannot] condition the exercise of the . . constitutional right to travel on the voluntary relinquishment of . . . Fourth Amendment rights." United States v. Lopez, 328 F. Supp. 1077, 1092-93 (E.D.N.Y. 1971); United States v. Meulener, 351 F. Supp. 1284, 1288 (C.D. Cal. 1972).

176 See note 166 supra; text at note 206 infra.

177 See text and notes at notes 166-169 supra.

178 Validity is a threshold statistical matter; it means that the Profile would have to turn up more potential hijackers than would be produced by a random selection of passengers who were then subjected to magnetometer screening, interrogation, and frisk. But beyond this threshold validity, the information provided by the Profile would, as a matter of law, also have to be found to be sufficiently specific and articulable to justify the limited intrusion inherent in the magnetometer. 
tion of carry-on luggage. Nonetheless, even passengers who are frisked should be given the option of not boarding the aircraft before their carry-on luggage is inspected. The luggage search constitutes what the Court in Terry termed a "full-blown search," and may not be necessary to protect the officer and those nearby provided that the passenger consents not to board the flight. It should, therefore, be supported by nothing less than probable cause. Unless the suspect insists on boarding, such support is lacking. In any event, both magnetometer screening unsupported by Profile selection and dragnet searches of all passengers' carry-on luggage-the procedures mandated by the FAA's December 5 th rules ${ }^{170}$ - seem constitutionally impermissible.

\section{The Cost of Searching and Alternatives}

In addition to the constitutional problems they raise, the cost of magnetometer screening and the universal carry-on luggage search mandated by the FAA seems excessive when compared to the costs of the hijackings they are intended to deter. Several kinds of costs are incurred when an aircraft is hijacked. First, there are costs involved in operating the aircraft over the extra distance it must travel due to the diversion, including the costs of fuel, wear-and-tear on the plane, extra maintenance, landing fees, and compensation of crew. Occasionally, there may be a ransom paid that is not recovered. There is also the actuarial value of the dangers imposed by hijackings-the value of the injuries that may occur to persons on the plane or on the ground and of the damage that may be done to the aircraft or other property, discounted by the probability that such losses will occur. Its dollar amount is perhaps best approximated by any increased insurance premiums that airlines have to pay as a result of the threat of hijacking. Hijacking involves, as well, less easily quantifiable costs related to the inconvenience hijackings impose upon passengers. Passengers aboard the hijacked plane will be delayed in reaching their planned destination; passengers planning to board the plane at its scheduled stop and travel to its next destination will either be delayed or some alternative cost will be incurred for a replacement plane and crew. Finally, it is possible that fear of hijacking causes anxiety to potential passengers thus reducing the perceived benefits of air travel and, perhaps, resulting in a diminution of the number of passengers who choose air travel over alternative means of transportation.

The costs of preventing hijacking are of three principal varieties: operating costs, capital costs, and delay. Operating expenditures pay 
the salaries of armed guards and personnel who perform the carry-on search, apply the Profile, and monitor the magnetometer. Capital costs include the training of these persons and the acquisition of magnetometers. Delay occurs because travelers may have to get to the airport earlier due to the search; a person who arrives late may, because a search is required, miss his flight altogether. ${ }^{180}$ Finally, there is a certain psychological cost associated with the inconvenience and insult that the search procedure entails.

The FAA has never attempted to quantify in dollar terms the costs of the items on both sides of the hijacking balance sheet. ${ }^{181}$ Some tentative conclusions can be drawn, however, on the basis of the limited data available. Although the costs resulting from the additional operation of the aircraft and services of the crew during hijackings have never been calculated, these costs are precisely the same as those involved in the day-to-day operation of the aircraft and can be approximated by application of the rates airlines charge for the charter of planes and crew. ${ }^{182}$ Although ransom money has occasionally been paid, it has quite often been recovered and this cost is likely to be small. 183 Despite initial concern that insurance premiums would rise, ${ }^{184}$ the actuarial value of the dangers involved in hijacking is so slight that the insurance premiums paid by airlines have not been increased ${ }^{185}$ nor have carriers obtained special coverage for losses due to hijacking. ${ }^{186}$ The inconvenience to those aboard the few hijacked flights is, in all likelihood, balanced by the inconvenience to all passengers on all flights under the total security program mandated by the December 5 th order. ${ }^{187}$ And the reduction, if any, in air travel due to fear of hi-

180 See, e.g., Lindsey, supra note 122 (describing such an incident).

181 The Director of Security, Air Transport Association of America, states that "there are two studies underway in this regard." Letter from Harry J. Murphy, to The University of Chicago Law Review, Jan. 3, 1973.

182 The Boeing 727 aircraft has been the most frequent target of hijackers, having been attacked fifty-four times; the DC-8 is second, with twenty-eight attempts. Hijacking Statistics, supra note 3 , at 2 . The cost of chartering a 727 with crew is $\$ 2.35$ per mile plus a \$1,300 departure fee. Letter from Michael J. Fenello, supra note 72. Mr. Fenello noted that Cuba has imposed landing and servicing fees as much as $\$ 9,000$ (although on another occasion the fee was $\$ 1,620)$, depending on the length of stay in Cuba, but observed that "this cost is not of major importance." Id. See also note 199 infra.

183 Including the Southern Airways incident, see note 71 supra, extortionists have been paid $\$ 9.3$ million by U.S. air lines; all but $\$ 503,000$ has been recovered. Lindsey, 2-Million Ransom Imperils Airline, N.Y. Times, Nov. 6, 1972, at 1, col. 7; N.Y. Times, Dec. 25, at 33, col. 4 (reporting the recovery of the Southern Airways ransom).

184 See Wall Street Journal, Sept. 9, 1970, at 4, col. 2; id., Sept. 10, 1970, at 3, col. 1 . 185 Letter from Michael J. Fenello, supra note 72.

186 Letter from Howard Bisgard, Manager of Special Projects, United Air Lines, to The University of Chicago Law Review, Mar. 5, 1973.

$187 \mathrm{Mr}$. Fenello states that during February, 1973, the first complete month the airlines have operated under the FAA December 5 th rules, Eastern experienced an average of six 
jacking ${ }^{188}$ may well be balanced by the reduction in travel by persons unwilling either to go through the search procedure or to pay the addition to the price of air fares that the program may require.

At the same time, searching for hijackers can be quite costly. Prior to the December 5th order, direct dollar outlays for anti-hijacking programs were minimal. Since the Profile was applied and the magnetom. eter monitored as part of the normal responsibilities of airline agents, no additional personnel were needed. Capital costs were also small ${ }^{180}$ since the Profile/magnetometer system requires only slight training costs and the most commonly used magnetometer sells for about $\$ 1,000 .{ }^{180}$ The FAA's December order, however, will increase the cost of deterring hijacking significantly. The cost of personnel to search carry-on luggage and monitor magnetometers ${ }^{101}$ has been estimated at more than $\$ 50$ million annually. ${ }^{192}$ Some major trunk airlines have contracted with private investigative and security organizations to perform the carry-on search at a price of as much as $\$ 3$ million per carrier per annum, ${ }^{103}$ and airlines attempting to perform the searches with their own personnel will probably incur comparable costs. ${ }^{194}$ The cost of providing law enforcement personnel at all boarding gates will be

security delays a day of approximately nine minutes each, out of an average of 1359 scheduled departures daily. Letter from Michael J. Fenello, supra note 72. Even if this record remains constant over a twelve-month period, each of the forty attempted hijackings in 1969 would have had to result in an average per flight delay of nearly nine hours in order for the total delay due to hijacking in its peak year on all domestic airlines to equal the annual delay due to searching on Eastern alone. Under the "sterile concourse" concept in use at several large terminals, see Lindsey, Airports Restrict Public In a New Security Move, N.Y. Times, Dec. 31, 1972, at 1, col. 1, the searches are made at the entrance to the gate concourse instead of at the boarding gate for each individual flight. This should enable the airlines to avoid security delays. However, passengers will still be delayed; they will simply be required to arrive at the airport earlier in order to clear the security web in time to board their flight.

$188 \mathrm{Mr}$. Fenello states that Eastern is not aware of any decrease in air travel attributed to hijacking, but adds that passengers overwhelmingly favor antipiracy measures. Letter of Michael J. Fenello, supra note 72.

189 Eastern has spent about five hundred thousand dollars for weapons detection equipment. $I d$.

190 Letter and Ground Deterrence of Aircraft Hijacking, AN 107-2, supra note 132.

191 Since the airlines already used magnetometers fairly extensively, it seems reasonable to conclude that the bulk of the additional manpower will be required for carry-on luggage searching.

192 Lindsey, Airports Expect Delay on Guards, N.Y. Times, Dec. 30, 1972, at 42, col. I. The Times quoted the Air Transport Association as estimating that the cost to the nation's twenty-four major scheduled airlines would be about $\$ 56$ million. The ATA estimate, which amounted to more than $\$ 113$ million for implementation of the entire December program, is developed in detail in Aviation Daily, Jan. 2, 1973, at 7.

193 Wall Street Journal, Dec. 22, 1972, at 22, col. 3. Eastern, which has contracted out the carry-on search job, estimates its cost at $\$ 4$ million per year. Letter of Michael J. Fenello, supra note 72.

104 Wall Street Journal, Dec. 22, 1972, at 22, col. 3. 
nearly as great as that of searching hand luggage. The FAA order, which, as to armed security personnel, became effective on February 16, 1973, applies to each of the nation's 531 airports served by a certified carrier. ${ }^{105}$ Compliance with the order will require some 4,500 local law enforcement officers; ${ }^{190}$ the estimated $\$ 47$ million cost will be paid by municipalities, which, in turn, are expected to raise charges to airlines using their facilities. ${ }^{197}$ Thus, the total cost of implementing the new security requirements will be about $\$ 100$ million per annum. ${ }^{198}$ Whatever the precise cost of hijacking may be, it is doubtful that it even approaches this figure. ${ }^{199}$

There has been widespread objection to the new security requirements from municipalities and the airline industry. ${ }^{200}$ Although the FAA will train all supervisory personnel, local governments will be responsible for recruiting supervisors and for both recruiting and training those who serve under them. ${ }^{201}$ In many cases, local airport author-

19537 Fed. Reg. 25934 (1972).

196 Lindsey, supra note 192. Two hundred-thirty federal deputy marshals and 1,071 customs agents, coordinated by 327 employees of the FAA, have in the past provided security at 123 major United States airports. Witkin, Government to Issue Rule Requiring Airport Guards, N.Y. Times, Nov. 30, 1972, at 1, col. 6 (city ed.).

197 Lindsey, supra note 192. But see note 202 infra.

198 Buckhorn, Who'll Guard Against Air Piracy?, Chicago Daily Law Bulletin, Dec. 15, 1972 , at 1, col. 3; Lindsey, supra note 192.

199 A Boeing 727, the type of aircraft that has been hijacked most frequently, could, on the basis of the figures cited in note 182 supra, be chartered for an around the world flight for sixty thousand dollars. If each of the thirty-one attempted hijackings in 1972 had resulted in such a diversion, the total operational cost would have come to only about $\$ 1,860,000$. It has been conservatively estimated that a typical successful hijacking incident could cost as much as $\$ 25,000$, excluding extortion money and property damage and personal injury. Trilling, supra note 157 , at 6 .

200 See, e.g., Witkin, supra note 196; Lindsey, supra note 192.

201 Witkin, supra note 196. A bill passed by the Senate in 1972 would have provided for establishment of a consolidated airport security force under the FAA, with an annual budget of $\$ 35$ million. The Anti-Hijacking Act of 1972, S. 2280, 92d Cong., 2d Sess. (1972). The bill, strongly supported by the air transportation industry, died in the House under heavy White House pressure. Opening Statement by Senator Cannon, Hearings Before the Subcomm. on Aviation of the Senate Comm. on Commerce on the Administration's Emergency Anti-Hijacking Regulations, 93d Cong., 1st Sess. I (1973). The current S. 39, see note 168 supra, incorporates these provisions. However, the Fiscal Year 1973 Department of Transportation Appropriation Act, H.R. 15097, 92d Cong., 2d Sess., 86 Stat. 580 (1972) did permit the FAA to purchase and assign to the airlines $\$ 3.5$ million of detection equipment for use at United States airports. In separate statements made on December 5th, 1972, Secretary of Transportation John A. Volpe and Benjamin O. Davis, Assistant Secretary of Transportation for Safety and Consumer Affairs, stated that a substantial number of detection devices had been purchased and that $\$ 2.5$ million had been earmarked for additional purchases as needed. U.S. Dep't of Transportation, News, Remarks by Secretary of Transportation John A. Volpe, Announcing Air Transport Security Program, Dec. 5, 1972, at 2; U.S. Dep't of Transportation, News, Remarks by General Benjamin O. Davis Jr., Assistant Secretary of Transportation for Safety and Consumer Affairs, at News Conference on Expanded Air Security Program, Dec. 5, 1972 at 2. 
ities have long-term contracts with airlines that may preclude them from passing on the added costs of the program. ${ }^{202}$ Airline and airport officials are concerned that lack of uniformity in enforcement may result in liability if a person searched and frisked by local officers subsequently makes a hijacking attempt. ${ }^{203}$

These data present serious doubts concerning the wisdom of searching carry-on luggage and providing armed guards at every boarding gate. If these procedures were necessary, the free market would compel them. The Profile/magnetometer system became available in 1969, but the airlines, reluctant to jeopardize their image of providing safe and carefree travel, began using it only when it became clear that passengers welcomed such precautions. ${ }^{204}$ Before January, 1973, however, only two airlines had voluntarily begun searching carry-on luggage. ${ }^{205}$ If the decision to search had been left to the market, some airlines would probably have chosen to do so and others not. Passengers could then have selected among, for example, a flight that used total security, one that used only the Profile/magnetometer system, and one on which no precautions were used, all at slight differences in price. Ultimately, the market would have dictated the right combination of security procedures and cost.

Moreover, it is not at all clear that the additional security measures required by the December 5th order will be any more successful in eliminating all hijacking than were the limited measures previously in use. One of the two hijackings that led to the December rules involved a group of men who shot their way onto the aircraft; ${ }^{206}$ it is doubtful that an armed guard could have prevented such conduct. Neither the magnetometer nor luggage search can detect a person carrying a weapon

202 Letter of Donald L. Coe, Airport Commissioner, Chattaqua County Airport, Maryville, New York, to The University of Chicago Law Review, Mar. 8, 1973. Mr. Coe notes that Chattaqua County Airport is operated on a nonprofit basis and was operating at a deficit even before the new security program, which will force the airport deeper into the red. The airport's annual budget, exclusive of the cost of armed guards, was $\$ 114,000$. The armed guard requirement will be satisfied by using police officers from the nearby Town of Endicott and sheriff's deputies, at an annual cost of $\$ 12,000$. Mr. Coe believes that antihijacking procedures are needed, especially at larger airports, but that the major portion of the cost should be borne by the federal government: "A program of this sort can raise havoc with a small operation. When the Federal government can make a change in regulations and increase the cost of the airport operation $10 \%$ in one day, something should be done." Id. No flight departing from or bound for Chattaqua County Airport has ever been the target of a hijacking attempt. See Chronology of U.S. Hijackings, supra note 15.

203 Witkin, supra note 196. Lack of uniformity may also lead to abuse of civil rights by overzealous local police officers. See Lindsey, Ruling Restricts Airport Searches, supra note 144.

204 Fenello, supra note 6 , at 29.

205 See Wall Street Journal, Dec. 22, 1972, at 22, col. 3.

200 See note 71 supra. 
containing an amount of ferrous metal lower than that for which the magnetometer is tuned, or one made from an alloy. Finally, although the new measures may have a significant deterrent effect, ${ }^{207}$ it may be no greater than the deterrence that would be provided if the Profile/ magnetometer system were used on all flights.

The FAA and the airlines have claimed that because the number of successful hijackings has decreased since the development of the Profile/magnetometer system, the system is a success. ${ }^{208}$ But since the danger in hijacking occurs when an individual threatens a passenger or crew-member on board an aircraft, neither capturing a hijacker en route nor convincing him to surrender avoids the harm toward which an antihijacking program must be directed-attempted diversion of an aircraft from its planned route by violence or threat of violence against the aircraft, passenger or crew. To avoid this harm, potential hijackers must be deterred or prevented from boarding; the success or failure of hijackings is irrelevant in measuring the adequacy of an antihijacking system, except insofar as an increased rate of failure discourages future hijacking attempts.

The important factor is, therefore, whether the number of attempted hijackings has been reduced. Following development of the Profile/ magnetometer system, the number of attempts dropped somewhat ${ }^{209}$ and it is, of course, possible that a number of potential attempts were deterred. Following the January 31, 1972, order bringing antihijacking security measure under the FAA's direct control, there were two waves of extortion attempts in March and July; however, in the following five months the incidence of hijacking reached its lowest point in five years. ${ }^{210}$ It seems reasonable to conclude that the FAA's actions following the January 31 st order and preceding the December 5 th order were effective, along with other factors, in deterring hijackings. The FAA's December 5th order, motivated by the two violent hijackings in the fall of 1972, can be viewed as an attempt to eliminate the last vestiges of hijacking at a very high ( $\$ 100$ million) marginal cost. Even assuming that it can eliminate all hijackings, this large marginal

207 It is conceivable, however, that the measures will simply cause hijackers to use force before boarding the aircraft-in effect, moving the hijacking from the aircraft to the concourse. See N.Y. Times, Jan. 21, 1973, § 1, at 52, col. 3, describing an incident at an airport in Louisville, Kentucky, in which an AWOL soldier sprayed a crowded airport terminal with shotgun pellets and then seized an empty aircraft and an airline mechanic as hostage, threatening to blow up the aircraft if his demands were not met. The hijacker was ultimately subdued.

208 Fenello, supra note 6, at 30; Statement of Gen. Benjamin O. Davis, Jr., supra note 201, at 1 .

209 Chronology of U.S. Hijackings, supra note 15.

210 See text and notes at notes 60-71 supra. 
expenditure, with such wideranging effects, seems unwarranted, especially if less costly and equally effective alternatives are available.

One such alternative would be to employ, on all domestic flights, the limited, but apparently successful, Profile/magnetometer system that was used prior to the December 5th order, and to combine it with diplomatic and other initiatives aimed at removing the possibility that hijackers' objectives will be achieved. There have been four general categories of hijackers: political refugees, ${ }^{211}$ extortionists, terrorists, and, most recently, "fleeing felons." 212 The primary objective of refugee hijacking is political asylum, and the best means of preventing such hijacking seems to be the development of legal means of exit. Thus, the hijacking of Cuban planes to the United States ended soon after the Guban government agreed to allow United States planes to take its disaffected, or less useful, citizens to Miami..$^{213}$

The air extortionist of today resembles the sea pirate of the past. The best and most economical solution to the problem he poses is to take away his means of escape and to remove his safe havens. Parachute extortions have apparently been eliminated by sealing the ventral and tail cone exits of aircraft, thus making in-flight escape impossible. ${ }^{214}$ The two most popular havens, Guba and Algeria, have shown increasing interest in prosecuting or returning extortionists ${ }^{215}$ and may decide to join multinational conventions $\mathrm{s}^{\mathbf{2 1 8}}$ already signed by many nations,

211 Until the recent wave of extortionist hijackings, the dominant motive of hijackers was political. Aggarwala, supra note 9, at 8-10, 11 .

212 The term "fleeing felons" was coined by Federal District Court Judge J. L. Smith in an opinion denying an injunction barring implementation of the FAA's December armed guard regulation. Airport Operators Council Int'1 v. Shafer, 454 F. Supp. 79 (D.D.C. 1973).

213 See text and note at note 14 suppra. The recent termination of the Freedom Airlift may lead to a renewal of the Cuba-to-Miami traffic.

214 See text at notes 68-68 supra.

215 Under Scull and Crossbones, THE Economist, Nov. 18, 1972, at 12. Cuba announced that she had "absolutely no interest" in serving as a refuge for common criminals, see Szulc, Cuba and U.S. Say They Seek Accord to Curb Hijacking, N.Y. Times, Nov. 15, 1972, at 1 , col. 8 , and promptly proclaimed that she would try the perpetrators of the Southern Airways incident, note 71 supra. Gwertzman, Cuba Will Try 3 Hijackers; Accepts Proposal on Talks, N.Y. Times, Nov. 21, 1972, at 1, col. 6. More recently, the United States reached agreement with Cuba on the terms of an antihijacking treaty. Gwertzman, Rogers Says U.S. Is Firm on Cuba, N.Y. Times, Feb. 16, 1973, at 1, col. 5. For a discussion of the terms of the agreement, see note 221 infra.

210 The International Civil Aviation Organization (ICAO) and its Legal Committee have been responsible for three multinational conventions dealing with hijacking. Discussion first began in 1950, concerning the problem of jurisdiction over offenses committed on board an aircraft during flight over the high seas. Finally, at the IACO conference in 1963, in Tokyo, the Convention on Offenses and Certain Other Acts Committed on Board Aircraft was adopted and opened for signature. The Senate ratified it in 1969. 115 CoNG. REc. 11996 (1969). The Tokyo Convention required all signatories to "take all appropriate measures to restore control of the aircraft to its lawful commander or to preserve his 
promising to refuse hijackers sanctuary. It seems likely, therefore, that extortion hijacking will come to an end as nations discover that they derive no benefit from harboring such hijackers, and as their punishment of hijackers becomes more widely known.

The purpose of terrorist hijacking has generally been to focus attention on a particular political cause; ${ }^{217}$ in some instances, this purpose has been combined with political extortion or blackmail.218 If

control of the aircraft," and to "permit its passengers and crew to continue their journey as soon as practicable, and . . return the aircraft and its cargo to the persons lawfully entitled to possession." A harder-line American proposal, presented in an earlier draft and requiring all nations in whose territory a hijacked aircraft might land to punish the hijackers, was deleted altogether from the final draft adopted in Tokyo. The Tokyo Convention had obvious weaknesses. It did little more than set forth an obligation already implicit under international law governing foreign vessels in distress entering the port of another country. See Text of Convention on the High Seas, Geneva, 1958, reprinted in 38 U.S. DEP'T of STATE BULL. 1115 (1958). The Tokyo Convention contained no explicit provisions to curb or deter hijacking; there were, for example, no extradition provisions nor even a definition of the crime of hijacking.

In 1970, the International Conference on Air Law adopted the Hague Convention in response to the sharp increase in the number of hijackings in 1968 and 1969. By its terms, the unlawful diversion of an aircraft was made an offense, and each signatory is obligated to impose severe penalties for such acts and to extend its criminal jurisdiction to hijackers in its territory, regardless of where the hijacking occurred or the state of registration of the aircraft. If the state in which the hijacker is found does not extradite him, it must prosecute him. The Senate ratified the Hague Convention in 1971. 117 CoNG. REC. 30956 (1971).

In 1971, a diplomatic conference convened by the ICAO in Montreal adopted the Convention for the Suppression of Unlawful Acts Against the Safety of Civil Aviation. This Convention was deemed necessary by the wave of terrorist activities against aircraft and aircraft facilities in 1970, apparently related to the Middle East crisis. The provisions of the Montreal Convention parallel those of the Hague Convention. Acts of sabotage of aircraft, acts that endanger the safe flight of an aircraft by damaging it or destroying air navigation facilities, acts of violence against persons on board aircraft, and bomb hoaxes are defined as offenses. In the absence of extradition, local punishment is required. For a detailed history of the multinational conventions dealing with air pracy, see FitzGerald, Toward Legal Suppression of Acts Against Givil Aviation, 585 INT'L Conciltation 42 (1971).

Recognizing that stronger action may be necessary, the United States and Canada have recently proposed a new treaty that would provide for suspension of all air service to countries that fail to follow the rules set out in the Hague and Montreal conventions. Address by John R. Stevenson to the Ass'n of the Bar of the City of New York and the American Society of Int'l Law, Nov. 9, 1972, reprinted in 67 U.S. DEP'T of STATE Burc. 645,647 (1972). Such a threat was used successfully by the International Federation of Air Lines Pilots Association in 1968 to force prompt return of an $\mathrm{El} \mathrm{Al} \mathrm{aircraft} \mathrm{hijacked} \mathrm{to}$ Algeria. Aggarwala, supra note 9, at 26. Though such action would obviously provide a strong incentive for enforcement of antihijacking measures, inducing nations to comply with the terms of an agreement to which they are not parties may be considered inappropriate to an orderly system of international cooperation.

217 For example, the Jordan desert incident. See text and note at notes 40, 46 supra.

218 For example, the hijacking of a Lufthansa jet by Palestinian commandos followed by a demand for the release of three of the murderers of Israeli athletes at the Munich Olympics. N.Y. Times, Oct. 30, 1972, at 1, col. 1 . 
their belief in the righteousness of their cause is sufficient to spur them to risk their lives, terrorist hijackers are unlikely to be stopped by even the most drastic security measures. If, however, terrorist hijackings succeed in engendering only animosity for the cause they are intended to support, potential terrorists may recognize that their efforts would be self-defeating. Thus, the world outrage that resulted from the Jordanian desert incident in 1970 and the general support for the Israeli government's refusal to return Palestinian prisoners ${ }^{219}$ may explain why no similar exploits have since been attempted. ${ }^{220}$

The "pure" criminal, or "fleeing felon," may, like the terrorist, be so desperate that he is willing to shoot his way onto a plane. The only way to stop such a person is by convincing him that flight will be unavailing. The removal of safe havens, either by extradition to the country of origin or prosecution in the country of landing, will accomplish this objective. A substantial step toward the removal of Cuba as a safe haven occurred when that nation signed an antihijacking treaty with the United States in February, 1973.221

218 See, e.g., The Hijack War, 76 NewsweEk, Sept. 21, 1970, at 20; Drama on the Desert: The Week of the Hostages, 96 TIME, Sept. 21, 1970, at 18.

220 Following the Jordan desert incident, the Palestinians did not strike again for an entire year. In September and October, 1971, three Jordanian aircraft were unsuccessfully attacked, probably in retaliation for King Hussein's September, 1970, attack on Jordanbased commandos. A fourth Jordanian plane was unsuccessfully attacked in February, 1972. Again in February, 1972, the terrorists attacked a Lufthansa jumbo jet and were paid $\$ 5$ million in ransom by the German airline. In May, a Sabena airliner was hijacked to Tel Aviv and the release of captive commandos demanded; the Israelis foiled the terrorists, but one passenger was killed. Finally, a Lufthansa jet was hijacked and a successful demand made for the release of three terrorists held by the German government for the massacre of eleven Israeli athletes at the 1972 Munich Olympics. Domestic and Foreign Aircraft Hijackings, supra note 1 . Thus, aside from the four retaliatory attacks against Jordanian aircraft, there have been only three terrorist attempts since the desert incident in 1970. Of those three, one was for money and another was for prisoners. The target of both attacks was Lufthansa, the West German airline. At the time of the Jordan desert incident, West Germany promptly agreed to release Palestinian guerillas it held in return for German hostages. In view of this fact, it is not surprising that the guerillas picked Lufthansa in May, 1972, when they needed money. And in the light of these events, the October attempt to recapture the Munich murderers seems, in retrospect, to have been almost inevitable. The Sabena attempt seems a bit illogical, but may have been a desperate attempt to confront and embarrass the Israelis by presenting them with hostages on their own soil.

221 The treaty, signed on February 15, 1973, called for extradition or punishment with "the most severe penalty" of any person who "seizes, removes, appropriates or diverts from its normal route or activities any aircraft or vessel registered under the laws of one of the parties and brings it to the territory of the other ...." 68 U.S. DEP'T OF STATE BuLL. 260 (1973). The agreement provides, however, that in punishing hijackers, the parties may consider "any extenuating or mitigating circumstances" in cases in which the hijackers were "being sought for strictly political reasons and were in real and imminent danger of death without a viable alternative for leaving the country," provided there was no extortion of money or harm to passengers, crew, or others. Id. 


\section{ConClusion}

Airplane hijacking has affected only a very small proportion of the air traveling public. Yet the security measures required by the FAA to halt this menace touch every passenger and raise problems concerning the individual's fourth amendment rights. Summarily instituted in response to two violent hijackings in the fall of 1972, their cost is great and their value questionable. On the other hand, the more limited security measures relied on prior to 1973 seem to meet constitutional standards and appear more rational from the standpoint of cost and effectiveness. The Profile/magnetometer search procedure was never made mandatory for all domestic flights prior to the December 5th order. Indeed, implementation of any preboarding security measures was totally voluntary until the January 31,1972 order, and even then some discretion was left to the airlines. Yet, coupled with the regularization of exit procedures for Americans wanting to go to $\mathrm{Cuba}$ and once the parachute extortion gambit had run its unsuccessful course, these measures led, in the last half of 1972, to the lightest period in United States hijacking history since the "epidemic" began in 1968. The majority of commentators agree that the most effective and least expensive way to halt hijacking is by international treaty sealing off safe havens to the sky pirate. ${ }^{222}$ In view of these considerations, the December 5th order seems clearly excessive and should be rescinded in favor of a constitutionally supportable procedure on every flight, or perhaps simply a voluntary system dictated by market considerations.

Douglas M. Kraus

222 See sources cited at note 7 supra. 